\title{
EFEKTIVITAS KELEMBAGAAN PARTISIPATORIS DI HULU DAERAH ALIRAN SUNGAI CITARUM
}

\author{
Efectivity of Participatory Institution in Citarum River Upstream Watershed
}

\author{
Siti Halimatusadiah ${ }^{*}$, Arya Hadi Dharmawan, dan Rina Mardiana \\ Departemen Sains Komunikasi dan Pengembangan Masyarakat, Fakultas Ekologi Manusia, IPB \\ *)Email : halimatusadiahsiti@yahoo.com
}

Diterima 4 Januari 2012 / Disetujui 2 April 2012

\begin{abstract}
Upstream watershed is one of the sub-watersheds that serve to maintain the availability of water for the central and downstream region. So that, when damage occurs in that area, it will effect to the middle and lower area of the watershed. The purposes of this study were (1) to determine the stakeholders who involved in the rescue of Citarum watershed upstream, (2) to know the effectiveness of participatory institutions to change attitudes and behavior of society around the Citarum watershed upstream. This study was conducted using a quantitative approach supported by qualitative approach. Meanwhile, the results of this study showed (1) institutional participatory have successfully changed attitudes and behavior of society to not to dispose the household garbage and sewage into the river again (2) participatory institutional not yet managed to change the manner of private parties to not to dispose garbage and industrial waste into the river, and (3) participatory institutions in central are more effective to change society attitudes and behavior to be more concerned for the environment than the existing participatory institutions in the upstream. In generally, the participatory institutions have successfully established collaborative between public, private and government at the sub-watershed upstream.
\end{abstract}

Keywords: stakeholders, participatory, institutional, rescue of upstream watershed, community participation.

\section{PENDAHULUAN}

Barber (1997) menyatakan bahwa Daerah Aliran Sungai (DAS) merupakan suatu wilayah daratan yang merupakan satu kesatuan dengan sungai dan anak-anak sungainya serta berfungsi menampung, menyimpan dan mengalirkan air yang berasal dari curah hujan ke danau atau ke laut secara alami. DAS dapat dibagi ke dalam tiga komponen yaitu: bagian hulu, tengah dan hilir. Ekosistem bagian hulu merupakan daerah tangkapan air utama dan pengatur aliran. Ekosistem bagian tengah sebagai daerah distributor dan pengatur air, sedangkan ekosistem bagian hilir merupakan pengguna air. Hubungan antara ekosistem-ekosistem tersebut menjadikan DAS sebagai satu kesatuan hidrologis yang tidak dapat dipisahkan. Kesatuan pengelolaan DAS menjadi hal penting untuk dilakukan sebagai upaya untuk mengendalikan hubungan timbal balik antara sumberdaya alam dengan manusia dan segala aktivitasnya dengan tujuan membina kelestarian dan keserasian ekosistem serta meningkatkan kemanfaatan sumberdaya alam bagi kesejahteraan manusia (Barber 1997).

Kerusakan DAS yang terjadi saat ini dipercepat oleh peningkatan pemanfaatan sumberdaya alam sebagai akibat dari pertambahan penduduk, konflik kepentingan, kurangnya keterpaduan antar sektor, dan antara wilayah hulu-tengah- hilir. Degradasi DAS diperparah dengan pesatnya perkembangan ekonomi dimana banyaknya industri-industri menyebabkan meningkatnya permintaan terhadap sumberdaya alam hingga berujung pada tingginya tekanan terhadap DAS dan berakhir pada kerusakan ekosistem DAS (Dephut 2006). Deforestasi yang menyebabkan degradasi lahan di bagian hulu dan tengah DAS memicu terjadinya erosi yang berdampak pada sedimentasi di bagian hilir DAS. Prinsip interkonektivitas untuk daerah DAS sangatlah besar. Bila terjadi kerusakan di salah satu bagian DAS, maka akan mempengaruhi bagian DAS yang lain (Dephut 2008). Hingga saat ini, belum ada satu lembaga/instansi pengelolaan DAS yang dapat mengintegrasikan seluruh pemangku kepentingan dari berbagai sektor yang ada. T idak adanya pedoman yang sama yang digunakan oleh masing-masing sektor membuat pengelolaan terhadap DAS semakin terpecah-pecah dimana lembagalembaga pengelolaan DAS hanya bekerja pada wilayahnya masing-masing serta hanya berdasarkan batas wilayah administratif semata (Dephut 2008).

Salah satu langkah awal untuk mengatasi kerusakan DAS yang semakin parah adalah dengan membentuk gerakan masyarakat untuk bersama-sama melestarikan dan menjaga ekosistem DAS. Untuk membentuk gerakan masyarakat tersebut dibutuhkan suatu wadah yang dapat menampung aspirasi dan koordinasi dalam mengelola DAS. Prinsipnya kelembagaan DAS dibentuk atas kesadaran dan kebutuhan masyarakat sekitar DAS untuk melaksanakan pengelolaan DAS yang lebih baik sebagai akibat dari permasalahan-permasalahan yang 
timbul seperti konflik kepentingan antar sektor dan antar pemerintah daerah yang menyebabkan degradasi DAS. Pembentukan kelembagaan DAS harus didasarkan pada komitmen bersama dalam pencapaian tujuan pengelolaan DAS. Dengan keanggotaan kelembagaan demikian, maka akan terbangun komunikasi dan jejaring kerja (networking) diantara pemangku kepentingan yang terkait dengan pengelolaan DAS. Masing-masing pihak dapat memperoleh manfaat, peran, tanggungjawab dan membangun komitmen untuk mencapai tujuan bersama dalam meningkatkan kesejahteraan masyarakat dan melestarikan ekosistem DAS (Dephut 2003 b).

Upaya penyelamatan hulu DAS tersebut sangat bergantung pada sejauh mana kelembagaan yang terdapat di daerah hulu tersebut berperan dalam menjaga pelestarian lingkungan, fungsi dan kualitas air bagi sub DAS tengah dan hilir. Berdasarkan latar belakang yang dikemukakan di atas, penulis bermaksud mengkaji kelembagaan partisipatoris yang berada di hulu DAS Citarum (Sub DAS Cikapundung) dengan rumusan masalah penelitian, yaitu; sedalam dan seluas apakah pemangku kepentingan terlibat dalam upaya penyelamatan hulu DAS Citarum (Sub DAS Cikapundung)? serta bagaimana efektivitas kelembagaan partisipatoris dalam mengubah sikap dan perilaku masyarakat di sekitar hulu DAS Citarum (Sub DAS Cikapundung)?

\section{METODE PENELITIAN}

Pendekatan yang digunakan dalam penelitian ini adalah pendekatan kuantitatif yang didukung oleh pendekatan kualitatif. Dalam pendekatan kuantitatif, penelitian ini menggunakan metode survey. Penelitian survey adalah penelitian yang mengambil sampel dari satu populasi dan menggunakan kuisioner sebagai alat pengumpulan data pokok (Singarimbun 1989). Pendekatan kuantitatif digunakan untuk mengetahui sejauh mana masyarakat terkena dampak dari kegiatan-kegiatan yang dilakukan oleh kelembagaan partisipatoris di hulu dan tengah Sungai Cikapundung. Peneliti menggunakan metode studi kasus karena penelitian berada pada studi aras mikro, yaitu Sub DAS Cikapundung. Peneliti menggunakan triangulasi metodologi untuk menggali data kelembagaan partisipatoris dalam melaksanakan kegiatan- kegiatan penyelamatan hulu DAS Citarum (Sub DAS Cikapundung) dan juga keterlibatan pemangku kepentingan di hulu DAS Citarum (Sub DAS Cikapundung). Triangulasi yang digunakan adalah kombinasi dari teknik pengumpulan data dengan menggunakan metode wawancara mendalam, pengamatan berperan serta, dan kajian literatur.

Jenis data yang akan digunakan dalam penelitian ini adalah data primer dan data sekunder. Data primer diperoleh melalui wawancara dengan menggunakan kuesioner yang disebarkan dan diisi oleh responden melalui wawancara mendalam dan pencarian informasi kepada informan, sedangkan data sekunder diperoleh melalui dokumentasi dan studi literatur yang sumbernya berasal dari berbagai dokumen-dokumen pemerintah atau dinas-dinas terkait, buku, artikel, skripsi, tesis, internet dan karya ilmiah lainya.Terdapat dua subjek penelitian yaitu responden dan informan. Data dari penelitian kuantitatif diperoleh melalui kuisioner dengan menggunakan teknik wawancara kepada responden. Kemudian hasil dari kuesioner tersebut dicatat seperti apa adanya dan diolah dengan melakukan analisis serta interpretasi, baru selanjutnya dilakukan pembuatan kesimpulan tentang hasil kuesioner. Data dari penelitian kualitatif diperoleh melalui observasi ke lapangan dan wawancara mendalam kepada informan.

Untuk data kualitatif, penelitian ini menggunakan wawancara mendalam dengan pemangku kepentingan yang terlibat untuk mengetahui kegiatan-kegiatan kelembagaan partisipatoris dan peran dari masingmasing pemangku kepentingan serta untuk mengetahui faktor-faktor yang mempengaruhi kelembagaan partisipatoris dalam menjalankan upaya penyelamatan di hulu DAS Citarum (Sub DAS Cikapundung). Sedangkan untuk mengetahui perubahan perilaku dan tingkat kesadaran masyarakat setelah adanya kelembagaan partisipatoris digunakan data primer yang dikumpulkan melalui kuisioner yaitu sebanyak 60 responden dari dua Rukun Tetangga (RT) yang ditentukan secara purposif. Pemilihan RT ditentukan melalui teknik random sampling, dimana masing-masing RT akan diambil 30 secara acak.

Kerangka sampling dalam penelitian ini mengambil populasi masyarakat yang berada dekat dengan Sungai Cikapundung dan dekat dengan kelembagaan partisipatoris, terpilihlah Kecamatan Coblong yang terdiri dari enam kelurahan. Dari enam kelurahan terpilih dua kelurahan yang terbagi menjadi dua kelompok dengan karakteristik yang berbeda. Kelompok pertama adalah warga di Kelurahan Dago, Kecamatan Coblong yang merupakan daerah hulu Sungai Cikapundung dengan studi kasus komunitas CRP, sementara kelompok kedua adalah warga Kelurahan Lebak Siliwangi, Kecamatan Coblong yang sudah memasuki daerah tengah Sungai Cikapundung dengan studi kasus komunitas Zero. Dari kedua kelompok tersebut dipilih dua Rukun Warga (RW) secara purposif berdasarkan hasil pengamatan dan informasi yang terpercaya, kemudian dari kedua RW dipilih masing-masing satu RT secara purposif yang akan dijadikan sampel. RT yang terpilih yaitu RT 02/RW 01 Kelurahan Dago, Kecamatan Coblong dan RT

03/RW 08 Kelurahan Lebak Siliwangi, Kecamatan Coblong dimana kedua RT tersebut berdekatan langsung dengan Sungai Cikapundung. Dari masing-masing RT tersebut baru diambil secara acak rumah tangga yang akan dijadikan responden penelitian dimana jumlah total rumah tangga di RT 02/RW 01 sebanyak 63 dan di RT 03 RW 08 Kelurahan Lebak Siliwangi sebanyak 52 rumah tangga. Dari sini, dipilih secara acak 30 responden dari masing-masing RT untuk dijadikan sampel penelitian, sehingga jumlah total responden di dua lokasi berjumlah 60 rumah tangga.

\section{HASIL PENELITIAN}

\section{Gambaran Umum Sungai Cikapundung}

Sungai Cikapundung yang berhulu di Gunung Bukit Tunggul, Gunung Palasari dan Gunung Putri, berada pada ketinggian 650-2.067 m dpl merupakan Sub DAS Citarum yang luasnya $15.386,5$ ha dengan wilayah 
administrasi Kabupaten Bandung Barat, Kota Bandung, dan Kabupaten Bandung sepanjang $\pm 28 \mathrm{~km}$. Pada tahun 2010 Sungai Cikapundung memiliki curah hujan berkisar antara 1500-2400 mm/tahun, adapun hari hujan antara 96220 hari, sedangkan curah hujan maksimum $89 \mathrm{~mm}$. Tataguna lahan di Sungai Cikapundung meliputi: perkebunan sebesar 53,8 persen, pemukiman sebesar 25,3 persen, hutan sebesar 3,71 persen, sawah sebesar 6,62 persen, semak belukar sebesar 5,3 persen dan terakhir lahan kosong sebesar 5,64 persen. Populasi di wilayah sungai sekitar 750.000 jiwa. Sungai Cikapundung memiliki luas daerah tangkapan di bagian hulu sebesar $111,3 \mathrm{~km}^{2}$, di bagian tengah seluas $90,4 \mathrm{~km}^{2}$ dan di bagian hilir seluas $76,5 \mathrm{Km}^{2}$. Pada bagian hulu terdapat percabangan sungai yang membentuk dua sub sistem DAS, yang terletak di Maribaya. Percabangan kearah Barat merupakan sub sistem Cigulung meliputi Cikidang, Cibogo, Ciputri dan Cikawari, sedangkan kearah Timur meliputi sungai Cibodas dan Sungai Cigalukguk ${ }^{1}$.

Sungai Cikapundung termasuk kedalam 48 sungai yang mengitari Kota Bandung dan menjadi 13 anak sungai utama yang menjadi pemasok air bagi Sungai Citarum. Panjang alur Sungai Cikapundung yang melintasi Kota Bandung adalah sebesar $\pm 15,5 \mathrm{~km}(68,2$ persen dari total panjang sungai) dan diantaranya merupakan daerah pemukiman padat penduduk yang dipenuhi dengan 1.058 bangunan. Lebar sungai di hulu sepanjang 22 meter dan di hilir 26 meter, dimana debit air minimum sebesar enam meter kubik per detik. Sungai Cikapundung membelah Kota Bandung dengan melintasi sembilan kecamatan, 13 kelurahan dan 124 RW. Sungai Cikapundung terbagi dalam dua segmen antara lain kawasan hijau sepanjang lima kilometer meliputi wilayah Dago Bengkok Curug Dago - hingga Gandok, dan sepanjang 10,5 km daerah Gandok hingga Mengger bantarannya sudah merupakan daerah perumahan padat penduduk, perdagangan dan sebagainya.

Seperti fungsi sungai lainnya, Cikapundung pun berfungsi sebagai: (1) drainase utama pusat kota; (2) penggelontor kotoran dan pembuangan limbah domestik maupun industri sampah kota; (3) objek wisata Bandung (Maribaya, Curug Dago, kebun binatang dll); (4) penyedia air baku Perusahaan Daerah Air Minum (PDAM) Kota Bandung yang membangun instalasi penyadapan di Dago Pakar, Dago, dan di Badak Singa; (5) pemanfaatan energi yang dikelola oleh PT Indonesia Power-Unit Saguling yang mendirikan instalansi di PLTA Bengkok dan PLTA Dago Pojok, serta (6) sebagai sarana irigasi pertanian, namun seiring dengan pertumbuhan dan perkembangan kota, instalasi tersebut tidak berfungsi secara efektif. Merehabilitasi Sungai Cikapundung merupakan suatu langkah awal untuk merehabilitasi 13 sungai lainnya agar jernih kembali, dimana Sungai Cikapundung digunakan untuk menampung air pada musim kemarau, mengurangi sedimentasi lumpur keruh di Sungai Citarum, juga sebagai sumber listrik Ibukota Jawa Barat dan jaringan Jawa hingga Bali.

\section{Sejarah Pembentukan Kelembagaan Partisipatoris Sub Daerah Aliran Sungai Cikapundung}

Komunitas Cikapundung Rehabilitation Program (CRP) terbentuk pada akhir tahun 2009 tepatnya pada 22 Desember 2009 di Curug Dago Bandung oleh LSM Penjelajah Rimba dan Pendaki Gunung (CAMEL) dan Dinas Kehutanan Tahura Ir.H Juanda, serta oleh salah satu Perguruan Tinggi Swasta di Bandung Institut Teknologi Nasional (ITENAS). Awalnya komunitas CRP merupakan salah satu program kerja dari Perhimpunan Penempuh Rimba dan Pendaki Gunung alam bernama CAMEL yang telah berdiri selama lebih dari 30 tahun lamanya sejak 5 Mei 1982 yang sekretariatnya berada di daerah Dago Bandung. Program tersebut berupa kegiatan konservasi alam dengan nama Cikapundung Rehabilitation Program. Program rehabilitasi Sungai Cikapundung tersebut dilakukan oleh anggota CAMEL atas dasar keprihatinan terhadap Sungai Cikapundung yang kondisinya semakin hari semakin memprihatinkan. Pada akhirnya program CRP tersebut terpisah dari LSM CAMEL dan menjadi sebuah komunitas tersendiri. Komunitas CRP senantiasa mengajak masyarakat di sepanjang Sungai Cikapundung untuk selalu berpartisipasi aktif menjaga dan melestarikan Sungai Cikapundung.

Komunitas CRP mensosialisasikan gerakan nyata di lapangan berupa gerakan bersih-bersih Sungai Cikapundung yang sekaligus menjadi awal terjalinnya hubungan masyarakat dan aparatur pemerintah mulai dari tingkat RT, RW, kelurahan, kecamatan, bahkan ketingkat Walikota dan Gubernur. Komunitas CRP merupakan pencetus gerakan rehabilitasi Sungai Cikapundung, hingga saat ini sudah terdapat \pm 42 komunitas yang melakukan kegiatan serupa komunitas CRP yang ditempatkan di beberapa posko/titik yang berbeda di sepanjang Sungai Cikapundung dengan berbagai nama komunitas yang berbeda-beda. Terbentuknya 42 komunitas pegiat sungai ini, dimulai saat komunitas CRP melakukan kegiatan pengambilan sampah dari Sungai Cikapundung hampir setiap harinya

\section{Gambaran Umum Kelurahan Dago (Hulu Sungai Cikapundung)}

Kelurahan Dago, Kecamatan Coblong merupakan salah satu bagian hulu Sungai Cikapundung yang berdekatan langsung dengan kelembagaan partisipatoris DAS (komunitas CRP). Kelurahan Dago memiliki luas lahan sebesar 258 ha. Secara geografis Kelurahan Dago memiliki bentuk wilayah datar/berombak yaitu sebesar 80 persen dari total keseluruhan luas wilayah. Ditinjau dari sudut ketinggian tanah. Kelurahan Dago berada pada ketinggian $100 \mathrm{~m}$ di at as permukaan air laut. Suhu ratarata di Kelurahan Dago berkisar $36^{\circ} \mathrm{C}$, sedangkan dilihat dari segi hujan sebesar $21 \mathrm{~mm} / \mathrm{thn}$ dan jumlah hari dengan curah hujan yang terbanyak sebesar 45 hari. Berikut pembagian penggunaan areal tanah di Kelurahan Dago:

\footnotetext{
${ }^{1}$ Data didapat dari PSDA Jawa Barat dan BPLH Kota Bandung
} 
Tabel 1. Penggunaan Areal Tanah Kelurahan Dago

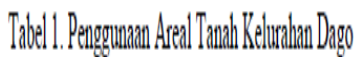

\begin{tabular}{|c|c|c|}
\hline$\sqrt{16}$ & 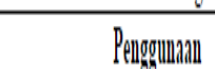 & $\operatorname{Lns}(\mid \mathrm{x})$ \\
\hline 1 & Trand Sarnd & 8,0 \\
\hline ? & 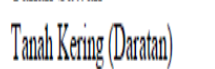 & 2884 \\
\hline 4 & 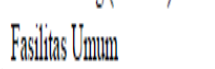 & $11 ., 6$ \\
\hline
\end{tabular}

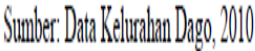

Hingga saat ini penggunaan tanah di Kelurahan Dago masih didominasi oleh tanah kering atau wilayah daratan yaitu seluas 228,94 ha, sedangkan fasilitas umum seluas 11,06 ha dan tanah sawah seluas 18 ha. Secara administratif Kelurahan Dago dibatasi oleh:

1. Bagian Selatan : Kelurahan Lebak Siliwangi

2. Bagian Utara: Kabupaten Bandung

3. Bagian Timur : Kelurahan Cigadung, Kelurahan Sekeloa, dan Kelurahan Lebak Gede

4. Bagian Barat: Sungai Cikapundung, Kelurahan Cimbuleuit, Kecamatan Cidada

Kelurahan Dago memiliki jumlah penduduk sebesar 29.662 jiwa pada tahun 2010 yang terdiri dari 14.501 jiwa laki-laki dan 15.161 jiwa perempuan dimana Jumlah kepala keluarga di Kelurahan Dago saat ini mencapai sekitar 7.127 KK. Berdasarkan kepercayaannya, sebagian besar penduduk Kelurahan Dago beragama Islam yaitu sebanyak 27.133 jiwa, agama Kristen sebanyak 1.544 jiwa, Kristen Katolik sebanyak 616 jiwa, agama Hindu sebanyak 239 jiwa, selanjutnya agama Budha sebanyak 85 jiwa, dan agama lainnya sebesar 45 jiwa. Dilihat dari segi kepadatan penduduk, Kelurahan Dago memiliki sebesar 99 jiwa per hektarnya dan dilihat dari pertumbuhan penduduk, intensitas populasinya akan terus bertambah dari waktu ke waktu. Penduduk di Kelurahan Dago sebagian besar berada pada usia produktif yang berkisar antara 15 tahun hingga 65 tahun yaitu sebanyak 31.203 jiwa. Untuk penduduk yang usianya belum produktif yaitu usia kurang dari 15 tahun sebanyak 4.932 jiwa dari total jumlah penduduk. Angka ini menunjukkan bahwa sebagian besar penduduk di Kelurahan Dago memiliki kemampuan untuk dapat memenuhi kebutuhan sehari-hari dimana jumlah penduduk usia produktif lebih besar dibandingkan dengan jumlah usia non produktif. Selanjutnya, disajikan tingkat pendidikan di Kelurahan Dago pada tahun 2010, dengan rincian sebagai berikut:
Tabel 2. Tingkat Pendidikan Kelurahan Dago, 2010

\begin{tabular}{|c|c|c|c|c|c|}
\hline \multirow{2}{*}{$\mathrm{N}_{0}$} & \multirow{2}{*}{ Pendidikan } & \multicolumn{3}{|c|}{ Jumlah Penduduk } & \multirow{2}{*}{ Persentase \% } \\
\hline & & Laki-Laki & Perempuan & Jumlah & \\
\hline 1 & TidakB Belum Sekolah & 2.220 & 2.403 & 4.623 & 15,6 \\
\hline 2 & Tidak Tamat SD & 1.051 & 1.030 & 2.081 & 7,01 \\
\hline 3 & Belum Tamat SD & 2.071 & 2.223 & 4.294 & 14,5 \\
\hline 4 & Tamat SD & 2.851 & 2.854 & 5.705 & 19,23 \\
\hline 5 & SLTP & 1.881 & 2.213 & 4.094 & 13,8 \\
\hline 6 & SLTA & 1.958 & 2.112 & 4.070 & 13,72 \\
\hline 7 & Akademi & 1.198 & 1.142 & 2.340 & 8 \\
\hline \multirow[t]{2}{*}{8} & Sarjana & 1.271 & 1.184 & 2.455 & 8,3 \\
\hline & Jumlah & 14.501 & 15.161 & 29.662 & 100 \\
\hline
\end{tabular}

Tabel 2. menunjukkan bahwa persentasi penduduk yang tidak atau belum sekolah, tidak tamat SD, dan belum tamat SD cukup tinggi yaitu sebesar 15,6 persen, 7,01 persen dan 14,5 persen atau sebesar 4.623 jiwa, 2.081 jiwa dan 4.294 jiwa. Sementara jumlah penduduk yang sudah tamat SD di Kelurahan Dago memiliki persentase tertinggi yaitu sebesar 19,23 persen atau sebanyak 5.705 jiwa, disusul dengan jumlah penduduk yang telah menyelesaikan SLTP sebesar 13,8 persen atau sebesar 4.094 jiwa dan penduduk yang telah menyelesaikan SLTA sebesar 13,72 persen atau 4.070 jiwa. Untuk lulusan akademi dan sarjana memiliki persentase terendah yaitu sebesar delapan persen dan 8,3 persen atau sebesar 2.340 jiwa dan 2.455 jiwa. Dari data tersebut dapat disimpulkan bahwa pada umumnya tingkat pendidikan di Kelurahan Dago masih rendah yaitu berkisar antara lulusan SD dan SLTP. Berikut disajikan jumlah penduduk di Kelurahan Dago berdasarkan mata pencaharian pokoknya sebagaimana pada Gambar 1 .

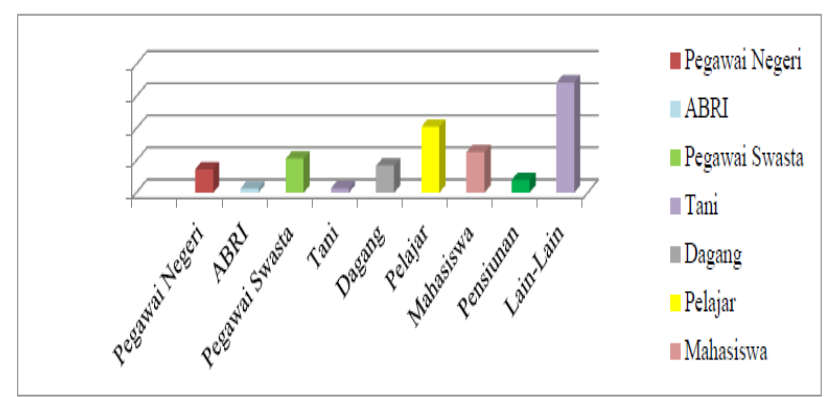

Gambar 1. Mata Pencaharian Penduduk Dago, Sub DAS Cikapundung, Bandung, Jawa Barat, 2010

Berdasarkan Gambar 1. mata pencaharian penduduk Kelurahan Dago didominasi oleh pegawai swasta sebesar 10,55 persen atau sebanyak 3.131 jiwa, mata pencaharian tertinggi kedua yaitu dagang sebesar 8,37 persen atau sebanyak 2.482 jiwa. Sementara 7,23 persen atau sebanyak 2.147 jiwa penduduk Kelurahan Dago bermata pencaharian sebagai pegawai negeri, empat persen atau sebanyak 1.182 persen sebagai pensiunan, selanjutnya 1,25 persen atau sebanyak 372 jiwa sebagai tani dan terakhir sebesar 1,23 persen atau sebanyak 365 jiwa bermata pencaharian sebagai ABRI. Untuk kategori lainlain sebesar 34,3 persen, dan untuk kategori pelajar sebesar 20,47 persen serta mahasiswa sebesar 12,60 persen tidak dimasukan ke dalam kategori mata pencaharian. Dari data diatas dapat disimpulkan bahwa 
pada umumnya penduduk Kelurahan Dago rata-rata bermata pencaharian sebagai pegawai swasta, pedagang, dan pegawai negeri.

\section{Kegiatan Lingkungan di Kelurahan Dago}

Kelurahan Dago merupakan salah satu daerah hulu Kota Bandung yang dijadikan pusat para peneliti lingkungan dan juga dijadikan sebagai tempat para pecinta lingkungan dalam melakukan kegiatan-kegiatan yang berhubungan dengan alam/lingkungan. Hal ini dikarenakan Kelurahan Dago merupakan wilayah yang masih asri dengan adanya ruang terbuka hijau, di Kelurahan Dago pun terdapat beberapa tempat sejarah seperti prasati peninggalan kerajaan Thailand di Curug Dago, Gua peninggalan Jepang dan Belanda, serta Taman Hutan Rakyat Insinyur Juanda, yang hingga kini masih dijadikan sebagai sarana objek wisata di kawasan Bandung Utara. Kelurahan Dago merupakan salah satu wilayah yang paling sering dituju oleh berbagai instansi atau masyarakat untuk melakukan penanaman pepohonan. Hal ini dikarenakan masih luasnya lahan terbuka hijau yang ada di Kelurahan Dago. Dahulu penghijauan atau reboisasi hanya dilakukan oleh instansi-instansi tertentu seperti dinas-dinas pemerintah, namun tak jarang setelah melakukan penghijauan kegiatan monitoring jarang dilakukan, sehingga pepohonan yang telah ditanam banyak yang tidak tumbuh, bahkan mati.

Seiring berjalannya waktu, Kelurahan Dago yang dijadikan sebagai kawasan objek wisata Bandung Utara, kian hari banyak dikunjungi oleh para pendatang yang berasal dari luar Kota Bandung. Banyaknya pendatang menyebabkan daerah hulu di Kelurahan Dago dipenuhi oleh pemukiman atau vila-vila yang menempati kawasan ruang terbuka hijau. Hal ini menyebabkan berkurangnya ruang terbuka hijau disamping penanaman pohon yang tidak dapat menyeimbangi laju kerusakan di hulu Kota Bandung. Namun setelah adanya komunitas-komunitas pegiat lingkungan seperti CAMEL dan CRP serta dengan adanya kelembagaan partisipatoris yang terdiri dari 42 komunitas pegiat Sungai Cikapundung maka kegiatan yang berhubungan dengan lingkungan tertutama penghijauan semakin gencar dilakukan di Kelurahan Dago. Saat ini, semakin hari di Kelurahan Dago kini semakin banyak pihak swasta yang melakukan Coorporate Social Responsibilities (CSR) yang berhubungan dengan lingkungan, bekerjasama dengan aparat setempat dan komunitas pegiat Sungai Cikapundung.

\section{Gambaran Umum Kelurahan Lebak Siliwangi (Tengah Sungai Cikapundung)}

Kelurahan Lebak Siliwangi merupakan salah satu kelurahan yang terdapat di Kecamatan Coblong yang memiliki banyak jumlah penduduk yang tinggal di bantaran Sungai Cikapundung. Secara geografis Kelurahan Lebak Siliwangi sudah termasuk ke bagian tengah Sungai Cikapundung, selain itu Kelurahan Lebak Siliwangi memiliki bentuk wilayah datar/berombak besar. Ditinjau dari sudut ketinggian tanah, Kelurahan Lebak Siliwangi berada pada ketinggian $750 \mathrm{~m}$ di atas permukaan air laut. Suhu rata-rata di Kelurahan Lebak Siliwangi berkisar $26^{\circ} \mathrm{C}$, sedangkan dilihat dari segi hujan berkisar 2433,63 mm/th dengan jumlah hari dan curah hujan terbanyak sebesar 45 hari. Kelurahan Lebak Siliwangi, Kecamatan Coblong merupakan salah satu wilayah pemerintahan Kota Bandung dengan luas wilayah 100 ha. Berikut pembagian penggunaan areal tanah di Kelurahan Lebak Siliwangi antara lain :

Tabel 3. Penggunaan Areal Tanah di Kelurahan Lebak Siliwangi, 2010

\begin{tabular}{|c|c|}
\hline 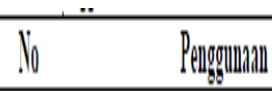 & $\operatorname{Lndx}(\ln )$ \\
\hline 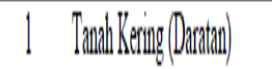 & Thth \\
\hline 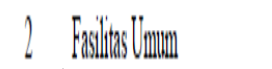 & 15th \\
\hline Jum & 1010h \\
\hline
\end{tabular}

Pada Tabel 3. terlihat bahwa penggunaan areal tanah di Kelurahan Lebak Siliwangi masih didominasi oleh tanah kering yaitu seluas 75 ha, kemudian fasilitas umum seluas 25 ha. Dari data tersebut dapat disimpulkan bahwa pada umumnya Kelurahan Lebak Siliwangi sudah tidak memiliki lahan basah seperti pada Kelurahan Dago. Secara administratif Kelurahan Lebak Siliwangi dibatasi oleh:

1. Bagian Selatan
Bandung Wetan Kel, Tamansari Kec,

\section{Bagian Utara: Kel. Dago Kec. Coblong}

3. Bagian Timur : Kel. Lebak Gede Kec. Coblong

\section{Bagian Barat: Kel. Cipaganti Kec. Coblong}

Sampai dengan Februari 2010 penduduk Kelurahan Lebak Siliwangi memiliki jumlah penduduk sebesar 4.422 jiwa yang terdiri dari 2.274 jiwa laki-laki dan 2.148 jiwa perempuan. Jumlah kepala keluarga di Kelurahan Lebak Siliwangi saat ini mencapai sekitar 1.088 KK. Jumlah tersebut lebih kecil dibandingkan dengan jumlah penduduk di Kelurahan Dago. Berdasarkan kepercayaannya, penduduk Kelurahan Lebak Siliwangi yang beragama Islam sebanyak 3.178 jiwa, Kristen Protestan sebanyak 297 jiwa, Kristen Katholik sebanyak 199 jiwa, yang beragama Hindu sebanyak 73 jiwa sedangkan yang beragama Budha sebanyak 105. Berdasarkan data kependudukan dari kelurahan, pada tahun 2010 Kelurahan Lebak Siliwangi memiliki kepadatan penduduk sebesar 44 jiwa per hektar dan dilihat dari pertumbuhan penduduk, dimana intensitasnya akan terus bertambah dari waktu ke waktu. Penduduk di Kelurahan Lebak Siliwangi sebagian besar berada pada usia produktif yang berkisar antara 15 tahun hingga 65 tahun yaitu sebanyak 3.393 jiwa. Untuk penduduk yang usianya belum produktif yaitu usia kurang dari 15 tahun sebanyak 1.029 jiwa dari total jumlah penduduk. Angka ini menunjukkan bahwa sebagian besar penduduk di Kelurahan Lebak Siliwangi memiliki kemampuan untuk dapat memenuhi kebutuhan sehari-hari dikarenakan jumlah penduduk usia produktif lebih banyak dibandingkan jumlah penduduk yang belum atau tidak 
produktif. Selain itu, sumber daya manusia di Kelurahan Lebak Siliwangi berdasarkan tingkat pendidikannya, berikut diperlihatkan dalam Tabel 4.

Tabel 4. Jumlah Penduduk Kelurahan Lebak Siliwangi Berdasarkan Tingkat Pendidikan, 2010

\begin{tabular}{|c|c|c|c|c|c|}
\hline \multirow{2}{*}{$\mathrm{N}_{0}$} & \multirow{2}{*}{ Pendidikan } & \multicolumn{3}{|c|}{ Jumlah Penduduk } & \multirow{2}{*}{ Persentase \% } \\
\hline & & Laki-Laki & Perempuan & Jumlah & \\
\hline 1 & Belum Sekolah & 276 & 248 & 524 & 11,85 \\
\hline 2 & Tidak tamat SD & 178 & 170 & 348 & 7,88 \\
\hline 3 & Belum tamat SD & 258 & 275 & 533 & 12,06 \\
\hline 4 & Tamat SD & 288 & 273 & 561 & 12,7 \\
\hline 5 & Tamat SLTP & 359 & 389 & 748 & 1692 \\
\hline 6 & Tamat SLTA & 377 & 347 & 724 & 16,38 \\
\hline 1 & Sarjana Muda (D3) & 274 & 226 & 500 & 11,31 \\
\hline 8 & Sarjana (SI) & 262 & 220 & 482 & 11 \\
\hline & Jumlah & 2272 & 2148 & 4420 & 100 \\
\hline
\end{tabular}

Sumber: Data Kelurahan Lebaks Siliwangi, 2011

Tabel 4. memperlihatkan jumlah penduduk di Kelurahan Lebak Siliwangi yang sudah memasuki usia sekolah sebanyak 3.886 jiwa dari total 4.422 jiwa. Untuk jumlah penduduk Kelurahan Lebak Siliwangi yang belum sekolah sebanyak 524 jiwa atau sebesar 11,85 persen, penduduk yang tidak tamat SD sebanyak 348 atau sebesar 7,88 persen, serta belum tamat SD sebanyak 258 jiwa atau sebesar 12,06 persen. Penduduk di Kelurahan Lebak Siliwangi yang telah tamat SD sebanyak 561 jiwa atau sebesar 12,7 persen, tamat SLTP sebanyak 748 jiwa atau sebesar 16, 92 persen, tamat SLTA sebanyak 724 jiwa atau sebanyak 16,38 persen, D3 sebanyak 500 jiwa atau 11,31 persen dan S1 sebanyak 482 atau 11 persen. Walaupun jumlah penduduk di Kelurahan Dago yang masih belum atau tidak tamat sekolah relatif lebih rendah dibandingkan dengan jumlah penduduk di Kelurahan Dago yaitu sebesar 1.405 jiwa, namun hal ini masih menunjukkan bahwa pada umumnya tingkat pendidikan di Kelurahan Lebak Siliwangi masih rendah. Adapun, jumlah penduduk Kelurahan Lebak Siliwangi berdasarkan mata pencaharian pokoknya adalah sebagai berikut:

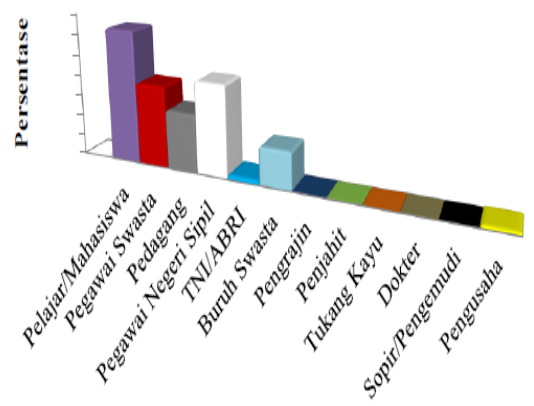

Gambar 2. Mata Pencaharian Penduduk Lebak Siliwangi, Sub DAS Cikapundung, Bandung, Jawa Barat, 2010

Berdasarkan Gambar 2 mata pencaharian penduduk Kelurahan Dago didominasi oleh Pegawai Negeri Sipil (PNS) sebesar 22 persen atau sebanyak 727 jiwa, kemudian pegawai swasta sebesar 19,74 persen atau sebanyak 650 jiwa, pedagang sebesar 14,15 persen atau sebanyak 466 jiwa. Selanjutnya, buruh swasta sebesar 9,08 atau sebanyak 299 jiwa, TNI/ABRI sebesar 1,12 persen atau sebanyak 37 jiwa, sedangkan untuk mata pencaharian pengrajian, penjahit, tukang kayu, dokter, sopir, dan pengusaha seluruhnya hanya di bawah satu persen. Hal ini menunjukkan bahwa rata-rata penduduk Kelurahan Lebak Siliwangi tergolong masyarakat ekonomi menengah. Adapun banyaknya jumlah pelajar dikarenakan daerah Kelurahan Lebak Siliwangi merupakan wilayah yang sangat dekat dengan salah satu perguruan tinggi negeri ternama di Kota Bandung. 6. Kegiatan Lingkungan di Kelurahan Lebak Siliwangi

Dahulu kegiatan lingkungan belum dijadikan prioritas utama karena belum terdapat lembaga atau organisasi masyarakat khusus yang menangani permasalahan lingkungan. Lembaga yang ada umumnya hanya berhubungan dengan masalah sosial dan ekonomi, belum ada lembaga yang dapat mempersatukan warga dengan masalah lingkungan. Namun pada akhir tahun 2010 terbentuklah beberapa komunitas lingkungan yang dipelopori oleh komunitas CRP, melalui komunitas CRP maka terbentuklah komunitas-komunitas lingkungan pegiat Sungai Cikapundung lainnya di daerah Lebak Siliwangi. Komunitas-komunitas inilah yang akhirnya dapat mempersatukan warga di Kelurahan Lebak Siliwangi dimana warga menjadi lebih peduli terhadap masalah lingkungan di sekitarnya khususnya peduli terhadap kelestarian Sungai Cikapundung yang telah mengalami kerusakan, dengan adanya komunitaskomunitas pegiat sungai tingkat solidaritas diantara warga pun semakin erat. Hingga kini di Kelurahan Lebak Siliwangi sendiri telah terdapat lima komunitas pegiat Sungai Cikapundung antara lain: komunitas Katak, komunitas Kumang, komunitas Lebah, komunitas Entog, dan komunitas Zero.

Komunitas Zero terbentuk atas keprihatinan terhadap kondisi bagian tengah Sungai Cikapundung yang sudah tercemar akibat perilaku warga RW 08 yang tinggal di bantaran Sungai Cikapundung dimana kebanyakan warganya membuang sampah ke sungai serta banyaknya sampah yang datang dari daerah hulu dan hanyut hingga ke wilayah tengah Sungai Cikapundung. Semakin lama, komunitas Zero semakin berkembang dan mendapat perhatian dari warga RW 08 dimana jumlah anggota komunitas Zero sendiri hingga saat ini \pm mencapai 100 orang yang terdiri dari berbagai kalangan, dengan jumlah anggota inti yaitu sebanyak 30 orang.

\section{Karakteristik Responden}

Umumnya karakteristik responden penelitian di dua kelurahan berbeda. Untuk Kelurahan Dago warga berada pada daerah hulu Sungai Cikapundung serta berlokasi dekat dengan lokasi komunitas CRP. Warga di Kelurahan Dago tidak tinggal di wilayah padat penduduk serta pada umumnya masih memiliki lahan terbuka hijau di daerahnya. Berbeda halnya dengan warga di Kelurahan Lebak Siliwangi yang sudah memasuki wilayah tengah Sungai Cikapundung serta berlokasi dekat dengan salah satu komunitas pegiat Sungai Cikapundung yaitu komunitas Zero, dimana wilayahnya sudah sangat padat 
dengan pemukiman penduduk. Selanjutnya disajikan gambaran karakteristik responden penelitian dari dua kelurahan berdasarkan jenis kelamin pada Tabel 5. berikut ini:

Tabel 5. Responden Berdasarkan Jenis Kelamin, Sub DAS Cikapundung, Bandung, Jawa Barat, 2011

\begin{tabular}{|c|c|c|c|c|c|c|}
\hline \multirow[b]{2}{*}{ Kelurahaw } & \multicolumn{2}{|c|}{ Laki-Laki } & \multicolumn{2}{|c|}{ Perempuan } & \multicolumn{2}{|c|}{ Total } \\
\hline & Jumlah & $\begin{array}{c}\text { Persentase } \\
(\%)\end{array}$ & Jumlah & $\begin{array}{c}\text { Persentase } \\
(\%)\end{array}$ & Jumlah & $\begin{array}{c}\text { Persentase } \\
(\%)\end{array}$ \\
\hline Dago & 22 & 73,33 & 8 & 26,67 & 30 & 100 \\
\hline $\begin{array}{l}\text { Lebak } \\
\text { Silimangi }\end{array}$ & 21 & 70 & 9 & 30 & 30 & 100 \\
\hline
\end{tabular}

Dari Tabel 5. terlihat bahwa responden di kedua lokasi penelitian tidak jauh berbeda. Jumlah responden laki laki di Kelurahan Dago sebesar 73,33 persen atau sebanyak 22 orang, sementara responden perempuan sebesar 26,67 persen atau sebanyak delapan orang saja. Untuk responden di Kelurahan Lebak Siliwangi jumlah responden laki-laki sebesar 70 persen atau sebanyak 21 orang, sedangkan responden perempuan sebesar 30 persen atau sembilan orang perempuan. Selanjutnya, responden di dua kelurahan diklasifikasikan berdasarkan umur adalah sebagai berikut:

Tabel 6. Responden Berdasarkan Umur, Sub DAS Cikapundung, Bandung, Jawa Barat, 2011

\begin{tabular}{|c|c|c|c|c|}
\hline \multirow{2}{*}{ Umur } & \multicolumn{2}{|c|}{ Kelurahan Daggo } & \multicolumn{2}{|c|}{ Kelurahan Lebak Slilirangi } \\
\hline & Jumlah & Persentase $(\%)$ & Jumlah & Persentase $(\%)$ \\
\hline 21-30 tahlun & 0 & 0 & 0 & 0 \\
\hline $31-40$ talun & 6 & 20 & 8 & 26,67 \\
\hline 41.50 tahlun & 7 & 23,33 & 12 & 40 \\
\hline$>50$ tahung & 17 & 56,67 & 10 & 33,33 \\
\hline Jumlah & 30 & 100 & 30 & 100 \\
\hline
\end{tabular}

Tabel 4.10 menunjukkan perbedaan umur antara Kelurahan Dago dengan Kelurahan Lebak Siliwangi. Umumnya responden Kelurahan Dago didominasi umur 50 tahun ke atas, sementara di Kelurahan Lebak Siliwangi rata-rata umur responden adalah 41 tahun hingga 50 tahun. Selain itu, untuk melihat tingkat pendidikan di kedua kelurahan berikut disajikan dalam Gambar 3.

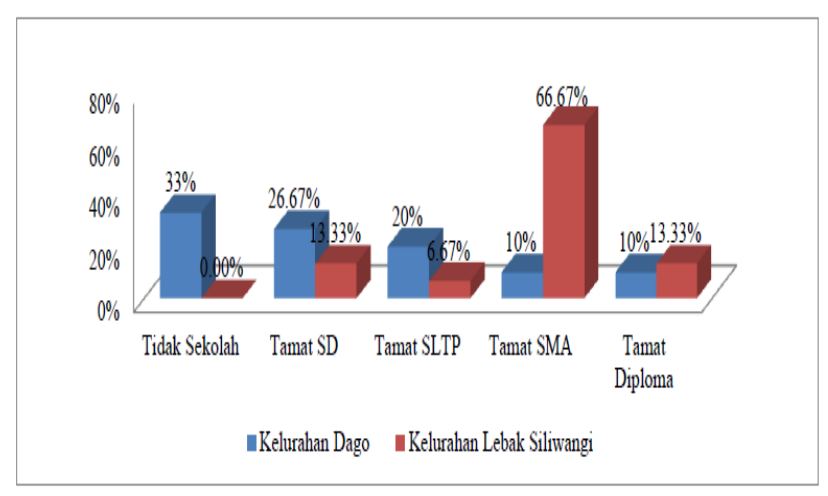

Gambar 3. Tingkat Pendidikan Responden Kelurahan Dago dan Kelurahan Lebak Siliwangi, Sub DAS Cikapundung, Bandung, Jawa Barat, 2011

Berdasarkan Gambar 3 terlihat bahwa tingkat pendidikan responden di Kelurahan Dago lebih rendah dibandingkan dengan tingkat pendidikan responden di Kelurahan Lebak Siliwangi, hal ini terlihat dari banyaknya jumlah responden di Kelurahan Dago yang tidak sekolah yaitu sebesar 33,33 persen dari total 30 responden atau sebanyak sepuluh orang. Responden yang tamat SD sebesar 26,67 persen atau sebanyak delapan orang, tamat SLTP sebesar 20 persen atau sebanyak enam orang, terakhir responden yang mengenyam bangku SLTA dan Diploma sebesar sepuluh persen atau sebanyak tiga orang. Rata-rata tingkat pendidikan di Kelurahan Lebak Siliwangi dari 30 responden yaitu: tamat SMA sebesar 66,67 persen atau sebanyak 20 orang, tamat SLTP sebesar 6,67 persen atau sebanyak dua orang, kemudian responden yang tamat SD dan Diploma sama-sama sebesar 13,33 persen atau sebanyak empat orang.

Rendahnya tingkat pendidikan responden di dua lokasi penelitian terutama di Kelurahan Dago mempengaruhi mata pencaharian responden. Responden di dua kelurahan yaitu Kelurahan Dago dan Lebak Siliwangi rata-rata merupakan masyarakat asli yang sudah lama tinggal sejak dahulu. Berikut disajikan kategori pekerjaan di dua lokasi penelitian yang dipaparkan pada Gambar 4.

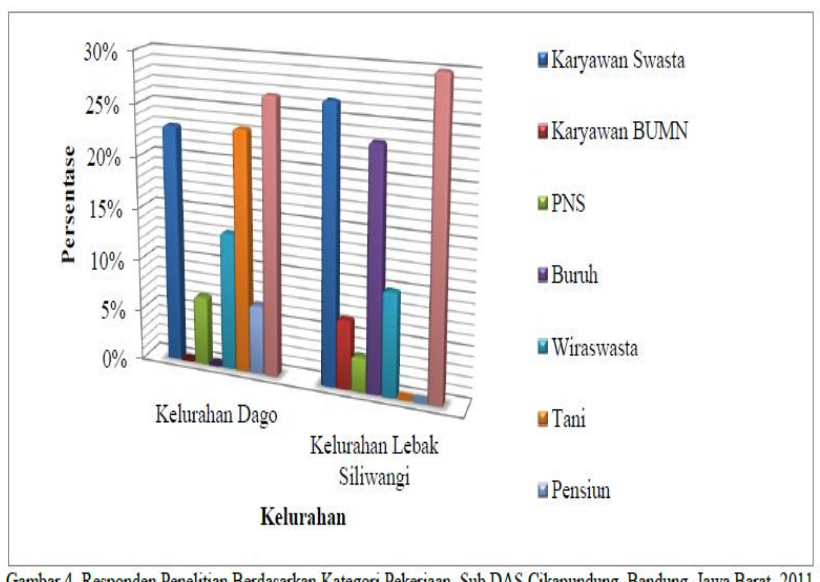

Berdasarkan gambar di atas terlihat bahwa karakteristik responden di dua lokasi penelitian sebagian besar tidak bekerja atau mengurus rumah tangga dimana di Kelurahan Dago sebesar 26,67 persen atau sebanyak delapan orang, sedangkan di Kelurahan Lebak Siliwangi sebesar 30 persen atau sebanyak sembilan orang. Hal ini dikarenakan sebagian besar responden yang tidak bekerja 
pada umumnya merupakan ibu rumah tangga. Responden yang bekerja sebagai karyawan swasta sebesar 23 persen atau sebanyak tujuh orang untuk Kelurahan Dago, dan 26,67 persen atau sebanyak delapan orang untuk Kelurahan Lebak Siliwangi. Responden yang bermata pencaharian wiraswasta sebesar 13,33 persen atau sebanyak empat orang untuk Kelurahan Dago dan sepuluh persen atau sebanyak tiga orang untuk Kelurahan Lebak Siliwangi, wiraswasta disini umumnya sebagai pedagang. Responden yang bermata pencaharian PNS hanya sebesar 6,67 persen atau sebanyak dua orang untuk Kelurahan Dago, dan sebesar 3,33 persen atau hanya sebanyak satu orang saja untuk Kelurahan Lebak Siliwangi.

Terdapat perbedaan pekerjaan antara Kelurahan Dago dengan Kelurahan Lebak Siliwangi, jika di Kelurahan Dago masih terdapat responden yang bermata pencaharian sebagai bertani, berbeda halnya dengan Kelurahan Lebak Siliwangi yang respondennya bekerja sebagai buruh, kedua pekerjaan tersebut di dua kelurahan yang berbeda sama - sama memiliki jumlah yang sama yaitu sebesar 23,33 persen atau sebanyak tujuh orang, perbedaan pekerjaan ini dikarenakan karakteristik lahan yang juga berbeda antara dua kelurahan dimana Kelurahan Dago masih memiliki lahan yang luas yang masih dapat ditanami, berbeda dengan Kelurahan Lebak Siliwangi yang lahannya sempit dan merupakan daerah pemukiman padat penduduk. Terakhir untuk responden di Kelurahan Dago yang sudah pensiun dan responden di Kelurahan Lebak Siliwangi yang bekerja di Badan Usaha Milik Negara (BUMN) memiliki besar yang sama yaitu 6,67 persen atau hanya sebanyak dua orang.

\section{Kerusakan Hulu Daerah Aliran Sungai Citarum (Sub Daerah Aliran Sungai Cikapundung)}

\section{Kepadatan Penduduk dan Limbah Domestik}

Banyaknya masyarakat yang tinggal di sepanjang Sungai Cikapundung menyebabkan padatnya pemukiman di wilayah tersebut. Pemukiman padat dapat dilihat terutama setelah memasuki kawasan tengah Sungai Cikapundung khususnya Kelurahan Taman Sari dan Kelurahan Lebak Siliwangi Bandung. Secara umum kondisi bantaran Sungai Cikapundung sudah sangat parah, hampir sepanjang 10,57 km bantaran Sungai Cikapundung dimanfaatkan menjadi bangunan rumah yang membelakangi sungai. Jumlah penduduk yang berdomisili di Sungai Cikapundung menurut Badan Pengelolaan Lingkungan Hidup (BPLH) Kota Bandung saat ini telah mencapai \pm 750.559 jiwa dengan jumlah penduduk tertinggi di Kelurahan Tamansari sebanyak 28.729 jiwa, dan bangunan pemukiman yang berada dekat dengan bantaran Sungai Cikapundung \pm berjumlah 1.058 rumah yang 90 persen limbah permukimannya langsung dibuang ke Sungai Cikapundung sehingga sungai ini menerima limbah lebih dari 2,5 juta liter/hari.

Secara kasat mata, sepanjang jalur yang dilewati sungai ini, banyak masyarakat yang memanfaatkan Sungai Cikapundung sebagai tempat pembuangan tinja dimana warga memasang pipa-pipa pembuangan limbah rumah tangga yang dialirkan langsung ke sungai. Selain itu, lebih dari 40 persen bantaran Sungai Cikapundung dijadikan lahan pertanian dan pemukiman sehingga menyebabkan kurangnya daerah resapan dan pengikisan tanah yang akhirnya membuat air berwarna coklat bercampur lumpur. Tidak hanya itu, tingginya sedimentasi di daerah hilir akibat banyaknya penebangan pohon dan alih fungsi lahan mengakibatkan kualitas air sungai menjadi semakin buruk. Gangguan keamanan hutan berupa pencurian pohon sebanyak 50 kali dalam satu tahunnya, sedangkan jumlah luas reboisasi rutin dan pembangunan di Bandung Utara pada tahun 2009 hanya sebesar 330 per ha.

\section{Aktivitas Swasta \\ Perusahaan Daerah Air Minum (PDAM)}

Kerusakan terhadap Sungai Cikapundung tidak terlepas dari campur tangan pihak swasta yaitu Perusahaan Daerah Air Minum (PDAM). Hal ini seperti yang dikemukakan oleh anggota komunitas CRP yang telah menelusuri asal limbah dan sampah yang ternyata berasal dari kedua perusahaan pemerintah tersebut. PDAM sendiri

mengaku bahwa pihaknya sudah sebaik mungkin mengatasi permasalahan sampah yang dibuang oleh warga di bantaran Sungai Cikapundung. Pihak PDAM sendiri mengaku kesal dengan warga yang masih membuang sampah rumah tangganya ke Sungai Cikapundung karena pada kenyataannya Sungai Cikapundung turut menyumbangkan air bagi PDAM yang nanti diolah menjadi air minum masyarakat. Namun, pihak PDAM mengaku bahwa saat ini Sungai Cikapundung sudah semakin bersih akibat adanya komunitas-komunitas pegiat sungai, untuk saat ini PDAM memanfaatkan air hanya di bagian hulu Sungai Cikapundung sebagai sumber air baku, sementara itu, untuk hilir Sungai Cikapundung kualitas air masih tergolong kurang baik untuk dijadikan sumber air baku yaitu termasuk kelas empat ${ }^{2}$.

\section{Pembangkit Listrik Tenaga Air (PLTA)}

Berbeda kasus dengan PDAM, dimana limbah yang dihasilkan Pembangkit Listrik Tenaga Air (PLTA Bengkok) (Indonesia Power) bukanlah sampah atau limbah rumah tangga, tetapi berupa sedimentasi yang dialirkan ke Sungai Cikapundung. Sedimentasi yang dihasilkan oleh PLTA Bengkok tersebut membuat Sungai Cikapundung semakin keruh dan dangkal dengan banyaknya jumlah pasir serta Lumpur. Berbagai teguran pun sudah dilakukan oleh berbagai pihak baik itu masyarakat maupun aparat pemerintah setempat, namun belum ada solusi yang tepat karena terkait masalah dana dan teknologi dari PLTA itu sendiri. Banyaknya instansi dan lembaga pemerintah yang berhubungan dengan pengelolaan air di kota Bandung tidak selalu menjanjikan Sungai Cikapundung ke arah yang lebih baik, hal ini dapat terlihat dari tidak adanya pedoman atau garis instruksi yang jelas, serta tumpang tindihnya tugas pokok dan saling lempar tanggung jawab instansi pemerintah satu ke instansi pemerintah lainnya sehingga tidak adanya garis kordinasi yang jelas atau tidak adanya kegiatan, aksi atau program yang sama antara instansi satu dengan instansi yang lainnya.

\footnotetext{
${ }^{2}$ Kelas empat termasuk dalam klasifikasi tercemar ringan
} 


\section{Peternakan Sapi}

Selama ini kelembagaan partisipatoris mungkin berhasil dalam mengubah perilaku warga bantaran Sungai Cikapundung untuk menyadarkan dan mengubah perilaku mereka agar tidak lagi membuang limbah rumah tangga ke Sungai Cikapundung. Namun, kelembagaan partisipatoris tidak berdaya untuk menyadarkan atau merubah perilaku para pelaku industri atau pengusaha yang hingga saat ini masih membuang limbah ke Sungai Cikapundung, terutama pelaku usaha yang banyak terdapat di hulu Sungai Cikapundung yang sudah mulai memasuki wilayah Kabupaten Bandung Barat. Banyaknya industri-industri di hulu Sungai Cikapundung menyebabkan Sungai Cikapundung menjadi keruh, hal ini dikarenakan industri-industri tersebut memanfaatkan sungai sebagai tempat pembuangan limbah mereka dengan cara menghanyutkannya langsung ke sungai atau mengalirkannya melalui pipa-pipa. Daerah hulu Sungai Cikapundung merupakan lokasi peternakan sapi perah. Setiap harinya sapi-sapi yang berada di Lembang dan sekitarnya menghasilkan limbah berupa kotoran sapi mencapai 330 ton per harinya. Seperti salah satu industri peternakan sapi terbesar yang berada di hulu Sungai Cikapundung tepatnya di kawasan Maribaya, Cibodas, Kabupaten Bandung Barat. Peternakan sapi tersebut membuang kotoran sapi lebih dari 750 ekor ke dua aliran sungai yang berbeda yaitu Sungai Cikapundung dan Sungai Cikawari. Setiap harinya satu ekor sapi menghasikan kotoran sapi sebanyak $30 \mathrm{~kg}$. Hanya sekitar lima persen yang dimanfaatkan menjadi pupuk selebihnya dibuang ke kali-kali kecil yang bermuara di Sungai Cikapundung.

Jika dianalisis, terlihat bahwa di hulu Sungai Cikapundung tepatnya di Kabupaten Bandung Barat, belum terdapat komunitas atau kelembagaan khusus yang mengakomodir permasalahan lingkungan khususnya sungai seperti yang ada di Kelurahan Dago dan Kelurahan Lebak Siliwangi. Selain itu, hingga saat ini Pemerintah Kota Bandung belum melakukan negosiasi dan kolaborasi kepada Pemerintah Kabupaten Bandung terkait industri peternakan sapi yang mencemarkan Sungai Cikapundung. Pemerintah Kota mengaku Pemerintah Kabupaten belum mengeluarkan kebijakan yang tegas terkait para peternak sapi yang membuang limbah kotoran sapi ke sungai. Setiap triwulannya komunitas CRP senantiasa mengadakan cek terhadap kualitas air di Sungai Cikapundung. Pada triwulan pertama (tahun 2008) sebelum diadakannya kegiatan penyelematan Sungai Cikapundung khususnya aksi kali bersih yang diadakan oleh komunitas CRP, kualitas air Sungai Cikapundung dinyatakan dalam keadaan buruk, hal ini dikarenakan banyaknya limbah/sampah rumah tangga dan industri yang dibuang langsung ke Sungai Cikapundung. Pada triwulan kedua (tahun 2009) setelah komunitas CRP melakukan kegiatan pembersihan sungai, maka kualitas Sungai Cikapundung membaik hal ini dikarenakan berkurangnya jumlah/volume sampah di Sungai Cikapundung. Namun pada triwulan ketiga (tahun 2010) setelah dibukanya peternakan sapi di hulu Sungai Cikapundung, kualitas air dinyatakan lebih buruk dibandingkan dengan kualitas air pada triwulan pertama, walaupun secara kasat mata, Sungai Cikapundung menjadi bersih dari

sampah akibat dari adanya komunitas-komunitas pegiat Sungai Cikapundung. Berikut disajikan data E.Coli yang terkandung dalam Sungai Cikapundung setiap tahunnya.

Tabel 7. Data Pengujian E.Coli Pada Sungai Cikapundung

\begin{tabular}{|c|c|c|c|}
\hline SungaiCikapundung & $\begin{array}{l}2008 \\
\mathrm{Jm} 110 \mathrm{ml}\end{array}$ & $\begin{array}{l}2009 \\
\mathrm{Jm} 1100 \mathrm{ml}\end{array}$ & $\begin{array}{l}2010 \\
\mathrm{Jm} / 100 \mathrm{~m}\end{array}$ \\
\hline Dagg Pakara (Hillu) & 150.000 & 1.100 & 46.000 \\
\hline Baknul|lutulu & 2000 & 2000 & 2000 \\
\hline
\end{tabular}

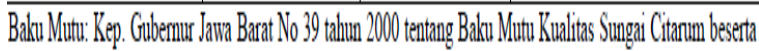

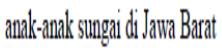

Sumber: BPLHKotat Bandung, 2010

Tabel 7. menunjukkan bahwa pada tahun 2008 sebelum adanya kegiatan aksi kali bersih yang dilakukan kelembagaan partisipatoris Sungai Cikapundung, kadar E.Coli yang terkandung di Sungai Cikapundung adalah sebesar $150.000 \mathrm{Jml} / 100 \mathrm{ml}$ hampir sekitar $75 \mathrm{kali}$ di atas baku mutunya, padahal toleransi baku mutu bakteri EColi adalah sebesar 2000 mikroorganisme per 100 mililiter air. Setelah adanya aksi bersih yang dilakukan oleh para komunitas pegiat Sungai Cikapundung, kadar E.Coli dalam Sungai Cikapundung mengalami penurunan yang cukup signifikan dimana kadar E.Coli hanya sebesar $1.100 \mathrm{Jml} / 100 \mathrm{ml}$, namun pada tahun $2010 \mathrm{kadar}$ E.Coli kembali meningkat menjadi $46.000 \mathrm{Jml} / 100 \mathrm{ml}$ atau sekitar 23 kali lipat di atas baku mutunya.

Menurut Badan Pengelola Lingkungan Hidup (BPLH) Kota Bandung status mutu air sungai menunjukkan bahwa Sungai Cikapundung sudah tergolong ke dalam kategori tercemar berat untuk kategori Kelas I (air baku air minum), Kelas II (sarana dan prasarana rekreasi air), dan Kelas III (pembudidayaan ikan air tawar serta peternakan) dalam PP No. 8/2001. Sungai Cikapundung hanya dinyatakan tercemar ringan pada kategori Kelas IV untuk mengairi tanaman. Tingginya kadar polutan terbesar Sungai Cikapundung adalah bakteri E-coli yang berasal dari tinja dimana masyarakat di sekitar bantaran sungai selama bertahun-tahun menggunakan sungai pemasok air baku terbesar bagi Sungai Citarum itu sebagai septic tank, selain itu kerusakan Sungai Cikapundung diperparah dengan tingginya kandungan limbah yang berasal dari pertanian yang tidak ramah lingkungan, peternakan, rumah tangga, pasar dan limbah industri.Keberadaan Sungai Cikapundung tidak bisa terlepas dari KBU (Kawasan Bandung Utara) di hulunya. Sebagai kawasan resapan, KBU memiliki andil terhadap kualitas dan kuantitas debit air-nya. Dengan Kondisi KBU saat ini maka, sudah tidak bisa lagi menjamin pasokan air yang memadai dan berkualitas terutama di musim kemarau dimana air yang mengalir dari hulu sama sekali tak menunjang penataan bagi hilir Sungai Cikapundung. Hingga saat ini gerakan penyelamatan Sungai Cikapundung baru terlihat di Kota Bandung, dimana upaya penyelamatan Sungai Cikapundung di Kabupaten Bandung masih dibatasi oleh batas-batas administratif, dan yurisdiksi. 


\section{Upaya Penyelamatan Sub Daerah Aliran Sungai} Cikapundung

\section{Aktifitas Kelembagaan Partisipatoris}

\section{Aksi Kali Bersih}

Kegiatan-kegiatan rutin yang selama ini telah dilakukan oleh kelembagaan partisipatoris baik komunitas CRP maupun komunitas Zero untuk menyelamatkan Sungai Cikapundung adalah dengan mengumpulkan sampah/limbah di sepanjang Sungai Cikapundung, hal ini dilakukan hampir setiap hari oleh anggota komunitas CRP dan Zero. Umumnya komunitas CRP dan Zero melakukan kegiatan aksi kali bersih bersama-sama pada hari sabtu dan minggu, menurut mereka kegiatan inilah yang menginisiasi dan menginspirasi warga di bantaran untuk bersama-sama menjaga Sungai Cikapundung. Biasanya selama dua hari komunitas CRP berhasil mengumpulkan sampah basah sekitar $250 \mathrm{~kg}$, berbeda halnya dengan komunitas Zero yang baru terbentuk pada pertengahan tahun 2010 dimana pada awal setelah terbentuknya komunitas Zero, komunitas ini dapat mengumpulkan sampah basah lebih dari $180 \mathrm{~kg}$ per harinya, hal ini dikarenakan wilayah kerja komunitas Zero yang sudah mulai memasuki wilayah tengah dan hilir, dimana komunitas Zero harus mengumpulkan sampah basah yang hanyut dari hulu Sungai Cikapundung.

Wilayah kerja kelembagaan partisipatoris sendiri hingga saat ini telah mencakup sepanjang $4,3 \mathrm{~km}$ dari Curug Dago hingga bantaran Sungai Cikapundung dan kini sedang memperluas wilayah kerjanya menjadi $8 \mathrm{~km}$ dari total keseluruhan panjang Sungai Cikapundung sepanjang $\pm 15,5 \mathrm{~km}$ dimana komunitas CRP menjadi pusat dari segala kegiatan yang berhubungan dengan Sungai Cikapundung. Namun wilayah kerja sepanjang $8 \mathrm{~km}$ tersebut hanya mencakup wilayah hulu dan tengah Kota Bandung saja, belum mencakup wilayah hulu Kabupaten Bandung yang mayoritas mata pencaharian masyarakatnya menjadi peternak sapi dan belum menyadari akibat yang ditimbulkan dari pembuangan limbah kotoran sapi tersebut ke Sungai Cikapundung. Kini \pm hanya tinggal sepanjang $7,5 \mathrm{~km}$ upaya penyelamatan Sungai Cikapundung yang dilakukan oleh kelembagaan partisipatoris yaitu mulai dari tengah hingga ke hilir Sungai Cikapundung, namun sayangnya upaya penyelamatan Sungai Cikapundung oleh kelembagaan partisipatoris ini baru terlaksana di Kota Bandung saja, belum sampai ke Kabupaten Bandung.

\section{Pelatihan Susur Sungai}

Kegiatan pemungutan sampah menggunakan boat atau ban di Sungai Cikapundung adalah kegiatan rutin yang selalu dilaksanakan oleh kelembagaan partisipatoris termasuk oleh setiap anggota komunitas CRP dan komunitas Zero. Dalam kegiatan tersebut diperlukan keamanan dan keselamatan yang memadai, terutama keamanan bagi anak-anak remaja baik itu yang melakukan pengambilan sampah atau hanya sekedar bermain-main di sepanjang bantaran Sungai Cikapundung.

Untuk saat ini, pelatihan susur sungai hanya diadakan oleh komunitas CRP yang meliputi cara menggunakan ban atau boat pada berbagai keadaan sungai, sehingga para remaja dapat terbiasa kukuyaan atau river boarding dengan berbagai situasi di sungai, terutama di arus yang deras. Pelatihan ini berguna untuk mengetahui dimana saja medan-medan sungai yang dapat dilalui dengan aman dan medan sungai yang berbahaya untuk dilalui. Untuk komunitas Zero memang tidak mengadakan pelatihan khusus seperti yang dilakukan oleh komunitas CRP, namun anggota komunitas Zero selalu mendampingi remaja yang baru pertama kali melakukan kukuyaan di Sungai Cikapundung.

\section{Aksi Tanam Pohon}

Kegiatan rutin lainnya yang dilaksanakan oleh komunitas CRP dan Zero adalah melakukan penghijauan di lahan kritis tepatnya di hulu Sungai Cikapundung di KBU. Aksi penghijauan tersebut berupa penanaman dan perawatan pohon (menjaga vegetasi yang sudah ada). Menurut salah satu anggota komunitas CRP, pada tahun 2010 kurang lebih sebanyak 12 kali penanaman pohon telah dilakukan oleh komunitas CRP di lahan-lahan kritis dekat aliran Sungai Cikapundung bekerjasama dengan berbagai pihak yaitu pemerintah, swasta, masyarakat dan juga pihak akademisi. Jumlah pohon yang telah ditanam oleh komunitas CRP pada periode tahun 2009-2010 adalah sebanyak 1300 pohon di area seluas lebih dari tiga ha yaitu di bantaran Curug Dago. Pada tahun 2011 komunitas CRP pun masih terus melakukan penghijauan di berbagai lahan kritis di daerah hulu Sungai Cikapundung.

Berbeda dengan komunitas Zero yang lokasinya sudah berada di wilayah tengah Sungai Cikapundung dimana kegiatan penghijauan pun sudah tidak dapat dilakukan di bantaran sungai yang sudah dipadati oleh pemukiman warga Lebak Siliwangi. Namun, komunitas Zero menyiasatinya dengan menanam pepohonan kecil untuk selanjutnya ditempatkan pada pot-pot kecil dan diletakkan di depan/pekarangan rumah warga guna membuat lingkungan di bantaran sungai tidak terlalu gersang. Komunitas Zero memiliki wilayah tersendiri jika ingin melakukan kegiatan penghijauan, tidak semua lahan di Kelurahan Lebak Siliwangi dapat ditanami pohon, di Kelurahan Lebak Siliwangi masih tedapat hutan kota yang masih dijaga oleh warga dan aparat pemerintah setempat. Dengan adanya hutan di tengah kota dapat mempermudah komunitas Zero untuk melakukan kegiatan penghijauan bersama warga, siswa-siswi, mahasiswa bahkan instansi-instansi/organisasi yang ada di Kota Bandung.

\section{Pelestarian Satwa dan Tanaman}

Kerusakan atau alih fungsi hutan serta pencemaran air Sungai Cikapundung menyebabkan punahnya beberapa satwa dan tanaman yang berada di sekitar hulu Sungai Cikapundung. Untuk itu, kelembagaan partisipatoris melakukan pengawasan dan pelestarian satwa yang masih terdapat di beberapa hulu Sungai Cikapundung. Kelembagaan partisipatoris yang tergabung dalam 42 komunitas pegiat sungai lainnya salah satunya komunitas CRP dan komunitas Zero turut melakukan kegiatan pelestarian ikan dengan menebar benih ikan di sepanjang Sungai Cikapundung. Selain itu, komunitas CRP dan 
komunitas Zero melakukan pelepasan burung agar dapat melestarikan pepohonan yang ada di bantaran Sungai Cikapundung sehingga suasana Sungai Cikapundung pada dahulu kala dapat dirasakan kembali pada saat ini. Komunitas CRP pun melestarikan satwa dan berbagai jenis tanaman langka yang hampir punah seperti tanaman kapundung, pandan bali, aron dan tanaman ampelas di sekitar hulu Sungai Cikapundung.

\section{Pengelolaan Sampah/Limbah}

\section{Mengelola Sampah Organik dan Non Organik}

Komunitas CRP mengelola sampah organik dengan membuat pupuk organik sendiri. Namun hingga saat ini, komunitas CRP masih berusaha mencari jalan keluar untuk mengelola sampah non organik khususnya sampah basah yang didapatkan dari hasil mengambil dari sungai (bersih-bersih Sungai Cikapundung), karena saat ini belum ada teknologi yang dapat mengelola sampahsampah basah non organik hasil dari limbah Sungai Cikapundung.

Komunitas CRP berharap dengan adanya dukungan dari berbagai pihak swasta, akademisi maupun pemerintah maka dapat membantu untuk memecahkan penanganan daur ulang sampah basah plastik. Untuk pengelolaan sampah organik, komunitas Zero mengaku bahwa hingga saat ini mereka belum dapat membuat pupuk organik atau kompos sendiri secara besar-besaran seperti apa yang telah dilakukan oleh komunitas CRP. Namun, komunitas Zero memanfaatkan sampah-sampah basah hasil bersihbersih kali seperti pepohonan, sampah plastik dan sampah lainnya yang hanyut untuk dijadikan kerajinan yang akhirnya dapat bernilai guna dan bernilai jual tinggi.

\section{Membuat Septic Tank Komunal}

Salah satu kerusakan Sungai Cikapundung disebabkan karena perilaku warga yang masih membuang hasil Mandi Cuci Kakus (MCK) ke Sungai Cikapundung. Kelembagaan partisipatoris serta pihak-pihak terkait lainnya seperti pemerintah kota, PDAM dan swasta bersama-sama untuk membantu warga agar tidak lagi membuang limbah domestik yaitu kotoran manusia ke Sungai Cikapundung dengan cara membuat septic tank komunal. Septic tank komunal ini dibuat bersama-sama warga dengan cara membuat pipa-pipa pada setiap keluarga dan mengalirkan kotoran manusia ke tempat yang telah dibuat di satu lahan kosong. Rencananya setiap RT yang dijadikan target, dapat mendapatkan satu septic tank komunal untuk dapat digunakan secara bersamasama oleh warga setempat. Sayangnya, pembuatan septic tank komunal ini terkendala masalah tempat (lahan kosong), dana, biaya dan kesadaran warga itu sendiri untuk mengelolanya.

Salah satu anggota komunitas Zero menuturkan bahwa untuk realisasi septic tank komunal di daerah bantaran Sungai Cikapundung seperti pada Kelurahan Lebak Siliwangi yang telah lama melakukan kegiatan membuang hasil MCK ke Sungai Cikapundung, septic tank komunal ini kurang dapat direalisasikan dikarenakan sangat tergantung pada lahan yang ada, karena pada umumnya lahan untuk membuat septic tank komunal di bantaran Sungai Cikapundung sudah sangat terbatas dimana jarak antar rumah sudah sangat padat. Realisasi septic tank komunal ini hanya dapat dilakukan di beberapa RT saja di Kelurahan Lebak Siliwangi (di daerah bantaran sungai). Untuk wilayah di hulu, anggota komunitas CRP menuturkan bahwa septic tank komunal masih sangat mungkin untuk direalisasikan melihat kondisi lahan yang ada, dimana masih terdapat lahan kosong untuk membuat lubang septic tank itu sendiri, namun pembuatan septic tank komunal ini pun seringkali menjadi pro-kontra diantara masyarakat yang setuju dan yang tidaksetuju dengan adanya septic tank komunal di masing-masing RT, untuk saat ini komunitas CRP dan aparat pemerintah setempat masih melakukan upaya pendekatan dan sosialisasi terhadap warga setempat.

\section{Menggunakan Teknologi Tepat Guna}

Berbagai ketersediaan teknologi baik itu teknologi yang dibuat secara swadaya oleh anggota komunitas CRP dan Zero maupun teknologi yang diberikan oleh pemerintah, swasta maupun lembaga atau organisasi lainnya seperti teknologi pencacah sampah, perahu karet, bak sampah dan alat-alat lainnya untuk mendukung kegiatan penyelamatan lingkungan khususnya terkait kelestarian Sungai Cikapundung, sangat membantu komunitas dan warga dalam melestarikan kebersihan lingkungan sekitar.

Komunitas Zero dan CRP seringkali membuat berbagai kreatifitas lainnya dengan bahan-bahan dasar limbah yang didapat dari hasil kegiatan kali bersih di Sungai Cikapundung, komunitas Zero dan CRP bahkan sudah dapat memproduksi perahu karet, pelampung dan ban sendiri dan kini dapat dijual dan disewakan kepada masyarakat luas, serta sebagai bukti keseriusan warga Cikapundung untuk persiapan membuat Sungai Cikapundung menjadi obyek wisata air di Kota Bandung.

\section{Penyuluhan dan Penyadaran Warga}

Komunitas CRP dan komunitas Zero mencoba melakukan aksi penyadaran khususnya penyadaran bagi masyarakat yang berada di sekitar bantaran Sungai Cikapundung, tidak hanya dengan penyuluhan namun juga disertai aksi langsung di lapangan bersama dengan warga. Aksi penyadaran warga tersebut, berupa penyadaran dalam hal tidak membuang sampah rumah tangga dan limbah ke sungai, pembuatan kompos serta penya daran dalam hal penghijauan. Penyadaran tersebut akan efektif bila disertai dengan aksi-aksi atau kegiatan langsung di tempat bersama warga. Bila hanya penyuluhan-penyuluhan tetapi tidak disertai aksi langsung bersama warga maka cara ini dinilai kurang efektif dan kebanyakan warga masih suka membuang sampah di sungai. Aksi langsung bersama warga beserta pemberian materi lingkungan yang disampaikan dalam satu waktu, sangat efektif dilakukan agar warga merasa malu untuk membuang sampah ke Sungai Cikapundung.

\section{Diskusi Sabtu-Minggu}

Diskusi yang diadakan oleh komunitas CRP setiap hari sabtu dan minggu yang diadakan di Curug Dago Bandung adalah kegiatan berupa kumpul bersama anggota komunitas CRP dan komunitas-komunitas pegiat Sungai Cikapundung lainnya tak terkecuali komunitas Zero. Kumpul bersama ini bertujuan untuk meningkatkan rasa 
solidaritas antar anggota kelembagaan partisipatoris Sungai Cikapundung itu sendiri. Agenda yang dibahas pada saat kumpul bersama ini biasanya membahas program-program dan mengevaluasi setiap kegiatan yang telah dilaksanakan oleh kelembagaan partisipatoris selama ini, serta membahas tantangan, hambatan dan keberlanjutan program-program untuk kelestarian Sungai Cikapundung kedepannya, adapun dalam diskusi sabtu minggu ini membahas permasalahan yang terjadi di Sungai Cikapundung dan juga membahas kebijakan serta program-program pemerintah terkait Sungai Cikapundung, namun tak jarang diskusi sabtu-minggu ini hanya berupa kumpul dan silaturahmi bersama anggota kelembagaan partisipatoris saja.

\section{Kegiatan Insidental}

Kegiatan insidental yang pernah dilakukan oleh kelembagaan patisipatoris yang dipelopori oleh komunitas CRP bekerjasama dengan lembaga lainnya adalah kegiatan Cikapundung Festival. Dalam kegiatan ini komunitas CRP dan pihak terkait lainnya mengadakan berbagai pagelaran permainan tradisional, olah raga, hiburan serta berbagai permainan air, seperti arung jeram, kukuyaan, river boarding, gogolondongan dan seseroan ${ }^{3}$. Kegiatan yang terselenggara atas kerjasama Wiasgar, komunitas CRP, Dispora Kota Bandung, Polrestabes Kota Bandung dan Karang Taruna Kota Bandung ini bertujuan untuk mendorong kesadaran masyarakat untuk menjaga dan merawat Cikapundung serta mendorong produktivitas kreasi-kreasi dari berbagai potensi yang tumbuh dan berkembang di sepanjang aliran Sungai Cikapundung. Dalam kegiatan festival ini panitia mengikutsertakan perwakilan dari 30 kecamatan di Kota Bandung, sehingga kegiatan ini diharapkan dapat diadopsi oleh kecamatankecamatan lainnya di Kota Bandung yang berada di bantaran sungai, hal ini dilakukan agar masyarakat tidak jijik lagi dengan sungai tetapi malah menggiatkannya. Dalam acara ini komunitas CRP sekaligus memperkenalkan kepada publik bahwa telah terbentuk sekelompok orang yang terdiri dari masyarakat asli Cikapundung yang memiliki visi misi untuk menyelamatkan Sungai Cikapundung dari kerusakan pembangunan.

Pada Juni 2011 komunitas CRP bersama 42 komunitas Cikapundung lainnya termasuk komunitas Zero mengadakan aksi kukuyaan di bantaran Sungai Cikapundung yang tercatat di Museum Rekor Dunia Indonesia (MURI) dengan peserta kukuyaaan terbanyak yaitu 821 orang. upaya pemecahan rekor Muri ini merupakan inisiatif warga yang tergabung dalam 42 komunitas peduli Cikapundung yang terdiri mulai dari warga di hulu, tengah hingga hilir bantaran Sungai Cikapundung, hal ini merupakan yang pertama dan belum pernah terjadi di Indonesia sebelumnya. Rekor Muri sendiri bukanlah tujuan dari diadakannya kegiatan kukuyaan ini, namun yang jauh lebih penting adalah penumbuhan kesadaran baru dalam diri masyarakat dalam menyikapi sungai.

\footnotetext{
${ }^{3}$ Salah satu permainan tradisional Jawa Barat
}

\section{Aktivitas Pemerintah}

Pemerintah memiliki peran yang sangat penting dalam menyelamatkan Sungai Cikapundung dari kerusakan. Sebelumnya sejak tahun 2004 dimana belum terbentuk komunitas CRP dan 42 komunitas pegiat Sungai Cikapundung lainnya, Pemerintah Kota Bandung khususnya telah memiliki program untuk merehabilitasi dan mencegah Sungai Cikapundung dari kerusakan, yaitu melalui program "Cikapundung Bersih". Dalam program tersebut pemerintah melibatkan lima kelurahan di tiga kecamatan, yaitu Kelurahan Lebak Siliwangi, Kelurahan Cipaganti, (Kecamatan Coblong), Kelurahan Tamansari, (Kecamatan Bandung Wetan), serta Kelurahan Babakan Ciamis dan Kelurahan Braga, (Kecamatan Sumur Bandung). Bentuk operasionalisasi gerakan Cikapundung Bersih ini terdiri dari tujuh tahapan yaitu, (1) bakti sosial; (2) pengerukan sedimen; (3) normalisasi sungai; (4) inventarisasi bangunan di bantaran sungai serta perubahan tata letak bangunan yang semula membelakangi menjadi menghadap sungai; (5) penataan sempadan sungai; (6) pembangunan bangunan air; dan (7) penghijauan. Namun hingga tahun 2009 program Cikapundung Bersih tersebut belum dapat memenuhi targetnya, dimana warga di hulu, tengah dan hilir Sungai Cikapundung masih melakukan pencemaran sungai berupa membuang limbah domestik ke sungai. Hal tersebut dikarenakan kurangnya sosialisasi program dan dukungan warga di bantaran Sungai Cikapundung, serta keterbatasan pemerintah dalam bidang sumberdaya manusia, dana dan kendala teknis lainnya.

Program Cikapundung Bersih kembali terdengar di awal tahun 2010 setelah terbentuknya komunitas CRP dan komunitas pegiat Sungai Cikapundung lainnya. Kesamaan visi untuk mengembalikan Sungai Cikapundung ke kondisi seperti dahulu kala menjadikan komunitas CRP dan aparat pemerintah saling bekerjasama dan mendukung satu sama lainnya. Di satu sisi, untuk mensukseskan program Cikapundung Bersih, pemerintah memerlukan bantuan kelembagaan partisipatoris untuk dapat mensosialisasikan program Cikapundung Bersih sehingga program tersebut mendapat dukungan dari warga khususnya warga di bantaran Sungai Cikapundung. Di sisi lain, kelembagaan partisipatoris pun sama halnya dengan pemerintah, dimana kelembagaan partisipatoris Sungai Cikapundung membutuhkan dukungan dari pemerintah untuk mendapat otoritas dan legalitas menjalankan kegiatan yang berhubungan dengan kelestarian Sungai Cikapundung, serta agar kegiatankegiatan kelembagaan partisipatoris lebih dikenal oleh warga di bantaran sungai.

Bersamaan dengan pecahnya Rekor Muri, Pemerintah Kota Bandung mulai mengaktifkan Peraturan Daerah (PERDA) Kota Bandung Nomor 11 Tahun 2004 tentang Ketertiban, Kemanan, dan Kebersihan (K3) dimana jika ada warga yang masih membuang sampah ke Sungai Cikapundung maka akan dikenai denda hingga Rp lima juta dan untuk perusahaan akan didenda Rp 50 juta atau kurungan tiga bulan penjara. PERDA Kota Bandung Nomor 11 Tahun 2004 tersebut bukanlah gertakan sambal semata dimana pemerintah telah membentuk satuan tugas yang terdiri dari warga dan Satuan Polisi Pamong Praja 
(SATPOL PP) yang bertugas untuk terus memantau Sungai Cikapundung. Namun hingga saat ini, SATPOL PP belum dapat menemukan warga yang membuang sampah langsung ke Sungai Cikapundung, hal ini disebabkan industri atau warga yang membuang sampah ke sungai sering tidak ketahuan dengan melakukannya secara sembunyi-sembunyi pada malam hari atau dengan menggunakan kendaraan pribadi seperti motor dan mobil. Menurut aparat setempat, PERDA Nomor 11 tahun 2004 tentang K3 belum sepenuhnya dapat diterapkan di kota Bandung sementara kesadaran warga masih kurang dimana denda uang belum bisa diterapkan baik kepada warga maupun industri-industri terkait. Kesadaran untuk merevitalisasi Sungai Cikapundung hanya dilakukan oleh Pemerintah Kota Bandung semata. PERDA Nomor 11 tahun 2004 tentang K3 serta penurunan SATPOL PP belum dapat diterapkan di wilayah Kabupaten Bandung. Berbedanya wilayah dan kebijakan di Kota dan Kabupaten Bandung akan tidak menyelesaikan permasalahan di hulu Sungai Cikapundung dimana hampir 50 persen warga Kabupaten Bandung Barat khususnya, hidup dari beternak sapi. Bersama-sama kelembagaan partisipatoris Sungai Cikapundung maka masyarakat sekaligus Walikota Bandung terus mewujudkan Sungai Cikapundung bersih sebagai ruang publik yang menyatu dengan fungsi lingkungan fisik, seni budaya, sosial dan ekonomi bagi warga Kota Bandung, serta membangun kesadaran dan partisipasi pemangku kepentingan untuk tidak membuang sampah dan limbah ke sungai.

\section{Aktivitas Swasta}

Banyaknya pihak swasta di Kota Bandung tidak selamanya membawa dampak buruk bagi Sungai Cikapundung, hal ini terlihat dari banyaknya pihak swasta yang seringkali melakukan Corporate Social Responsibilities (CSR) dengan melakukan penghijauan serta memberikan berbagai jenis bantuan terkait kelestarian lingkungan khususnya Sungai Cikapundung. Banyak pihak swasta yang telah bekerjasama dengan komunitas CRP dan komunitas pegiat Sungai Cikapundung untuk melaksanakan kegiatan penghijauan bersama masyarakat di Kelurahan Dago dengan melibatkan RW, RT hingga karang taruna untuk bersamasama menanam pohon di daerah lahan kritis di Curug Dago.

\section{Aktivitas Akademisi}

Kelembagaan partisipatoris di Sungai Cikapundung seringkali melaksanakan observasi-observasi untuk mengetahui kondisi atau untuk melakukan upaya penyelamatan terhadap Sungai Cikapundung. Disinilah pihak akademisi turut dilibatkan untuk membantu menganalisis lebih dalam mengenai permasalahan serta solusi terkait Sungai Cikapundung, pihak akademisi seringkali membantu komunitas pegiat Sungai Cikapundung menangani permasalahan lingkungan baik dalam rangka bakti sosial maupun praktek kerja lapang. Dengan bersama-sama bertukar pikiran dan pengalaman maka komunitas-komunitas pegiat Sungai Cikapundung dan para akademisi mendapat ilmu pengetahuan baru yang dapat saling melengkapi dan saling memberikan manfaat satu sama lain.

\section{Pengetahuan Sikap dan Perilaku Warga}

\section{Pengetahuan Warga Mengenai Sampah}

Selanjutnya, kondisi sungai Cikapundung menurut responden di dua kelurahan sebelum dan setelah adanya kelembagaan partisipatoris Sungai Cikapundung adalah sebagai berikut:

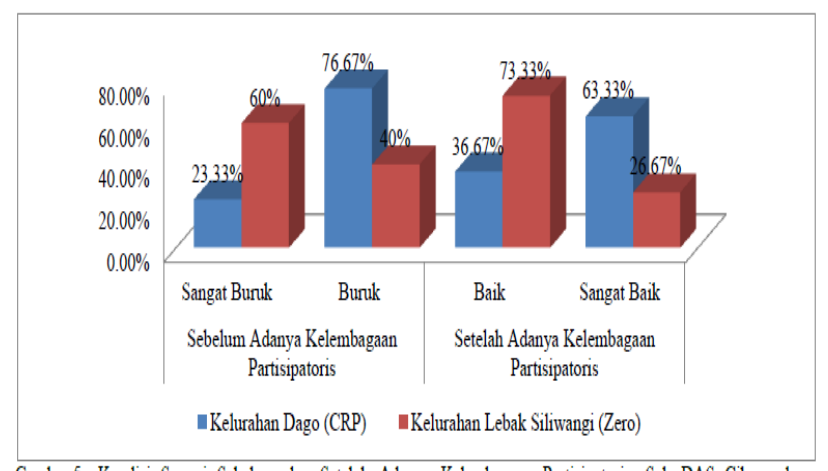

Gambar 5. Kondisi Sungai Sebelum dan Setelah Adanya Kelembagaan Partisipatoris, Sub DAS Cikapundung, Bandung, Jawa Barat, 2011

Pada Gambar 5 sebesar 23,33 persen responden di Kelurahan Dago menjawab kondisi Sungai Cikapundung sebelum adanya kelembagaan partisipatoris sangatlah buruk, sisanya sebesar 76,67 persen responden menjawab kondisi sungai dalam keadaan buruk. Berbeda dengan Kelurahan Lebak Siliwangi yang berlokasi sudah masuk wilayah tengah hingga hilir Sungai Cikapundung, dimana responden yang menjawab kondisi Sungai Cikapundung sangat buruk jauh lebih besar dibandingkan dengan responden di Kelurahan Dago yaitu sebesar 60 persen, sisanya responden yang menjawab kondisi sungai dalam keadaan buruk yaitu sebesar 40 persen. Setelah adanya kelembagaan partisipatoris Sungai Cikapundung kondisi sungai sudah sedikit mengalami perubahan walaupun perlahan tetapi pasti, dimana kondisi Sungai Cikapundung sudah jauh lebih baik. Sebagaimana terlihat pada jawaban responden di dua lokasi penelitian dimana setelah adanya kelembagaan partisipatoris di daerahnya, sebanyak 63,33 persen responden Kelurahan Dago menjawab kondisi sungai sangat baik dan sisanya sebesar 36,67 persen responden menjawab baik. Responden di Kelurahan Lebak Siliwangi yang menjawab kondisi sungai sangat baik hanya sebesar 26,67 persen serta responden yang menjawab baik sebesar 73,33 persen. Hal ini sesuai penuturan warga Kelurahan Lebak Siliwangi yang mengamati kondisi Sungai Cikapundung dari hari ke hari semakin baik. Umumnya kualitas air di hulu Sungai Cikapundung (Kelurahan Dago) masih lebih baik dibandingkan dengan kualitas air yang berada di tengah Sungai Cikapundung (Kelurahan Lebak Siliwangi). Hal ini terjadi karena wilayah hulu Sungai Cikapundung pada umumnya masih merupakan kawasan hijau dan bukan merupakan kawasan padat penduduk seperti di daerah tengah hingga hilir Sungai Cikapundung yang warna airnya sudah sangat coklat keruh.

\section{Pengetahuan Warga Mengenai Penghijauan}

Rata-rata responden di dua lokasi penelitian mengatakan bahwa adanya kegiatan penghijauan yang dilakukan adalah agar di daerahnya terdapat resapan air, ruang 
terbuka hijau, mencegah banjir dan juga longsor, serta agar lingkungan terlihat indah dan segar. Sementara itu, di dua lokasi penelitian yaitu Kelurahan Dago dan Kelurahan Lebak Siliwangi sama-sama tidak memiliki program penghijauan. Penghijauan dilakukan atas dasar inisiatif warga pada saat- saat tertentu saja. Walaupun program penghijauan tidak ada di dua kelurahan tersebut, namun warga mengaku masih sangat memerlukan penghijauan atau penanaman pohon di daerahnya masingmasing. Secara kasat mata responden diminta menilai kondisi lahan kritis di daerahnya sebelum dan setelah adanya kegiatan-kegiatan kelembagaan partisipatoris di Sungai Cikapundung, sebagaimana pada Gambar 6 di bawah ini:

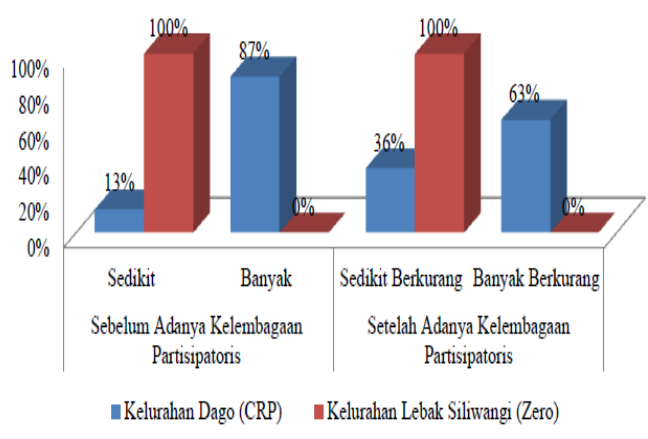

Gambar 6. Kondisi Lahan Kritis Sebelum dan Setelah Adanya Kelembagaan Partisipatoris, Sub DAS Cikapundung Bandung, Jawa Barat, 2011

Kondisi lahan kritis sebelum adanya kelembagaan partisipatoris Sungai Cikapundung dinyatakan banyak oleh 87 persen responden di Kelurahan Dago, dan sebesar 13 persen menyatakan lahan kritis tidaklah banyak di daerahnya. Jauh berbeda dengan kondisi lahan kritis di Kelurahan Lebak Siliwangi dimana 100 persen respondennya menjawab hanya ada sedikit lahan kritis di daerahnya. Perbedaan yang besar antara kedua kelurahan ini terjadi karena perbedaan karakteristik lahan antara wilayah hulu yang masih banyak terdapat lahan kosong dan wilayah tengah yang sedikit akan lahan kosong dan juga merupakan daerah padat pemukiman.

Setelah adanya kelembagaan partisipatoris dengan berbagai kegiatan penghijauannya, lahan kritis di dua lokasi penelitian pun sedikit demi sedikit mulai berkurang dimana kondisi lahan kritis untuk Kelurahan Dago setelah adanya kelembagaan partisipatoris di Sungai Cikapundung mengalami penurunan dimana sebesar 64 persen responden menjawab lahan kritis telah banyak berkurang, serta sisanya sebesar 36 persen responden menjawab lahan kritis sudah sedikit berkurang. Pada umumnya sebagian besar komunitas-komunitas pegiat Sungai Cikapundung setiap akan melakukan kegiatan penghijauan bersama dengan warga dan instansi-instansi sepeti swasta dan lembaga pemerintah lainnya, selalu menunjuk kawasan Curug Dago sebagai tempat untuk menanam bibit-bibit pohon yang daerahnya memang cocok untuk melakukan penanaman dan masih terdapat banyak lahan kritis.

Untuk Kelurahan Lebak Siliwangi tidak ada perubahan yang signifikan, namun sebesar 76,67 persen responden menjawab lahan kritis sudah sedikit berkurang, sementara sebesar 23,33 responden lainnya menjawab lahan kritis tidak berkurang sama sekali. Responden Kelurahan Lebak Siliwangi yang menjawab lahan kritis sudah sedikit berkurang adalah responden yang pernah mengikuti penghijauan atau hanya sekedar memantau lingkungan ruang terbuka hijau di daerah sekitarnya.

\section{Tingkat Keterlibatan Warga dalam Membuang dan Mengelola Sampah/Limbah Rumah Tangga}

Kesadaran warga untuk mengelola sampah rumah tangganya menjadi hal yang sangat berpengaruh terhadap kelestarian Sungai Cikapundung. Berikut perilaku warga dalam membuang limbah rumah tangganya sebelum adanya kelembagaan partisipatoris Sungai Cikapundung. Sebagaimana yang terlihat pada Gambar 2 dimana sebelum adanya kegiatan-kegiatan kelembagaan partisipatoris masih banyak warga di dua lokasi penelitian yang tidak menggunakan jasa pengangkut sampah. Berikut tempat pembuangan sampah yang digunakan oleh warga di dua lokasi penelitian sebelum dan setelah adanya kelembagaan partisipatoris, sebagaimana pada Gambar 3 di bawah ini.

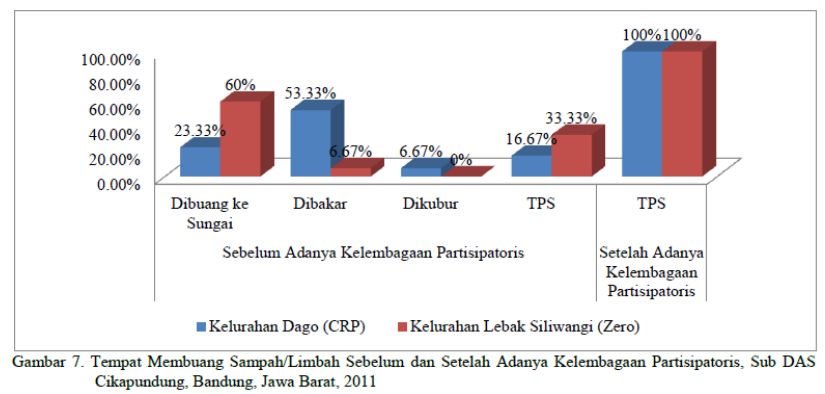

Pada Gambar 7 rata-rata responden Kelurahan Dago yang membuang sampah/limbah rumah tangga sebelum adanya kegiatan kelembagaan partisipatoris dengan cara dibakar yaitu sebesar 53,33 persen, dibuang ke sungai sebesar 23,33 persen, kemudian yang menggunakan Tempat Pembuangan Sampah (TPS) sebesar 16,67 persen dan sisanya dikubur sebesar 6,67 persen. Berbeda dengan Kelurahan Dago yang tidak semua warganya membuang sampah ke sungai, di Kelurahan Lebak Siliwangi rata-rata responden yang membuang sampah ke sungai sebesar 60 persen, sebesar 33 persen lainnya responden Kelurahan Lebak Siliwangi telah lebih dahulu menggunakan jasa TPS atau pengangkut sampah, selanjutnya sebesar 6,67 persen warga Lebak Siliwangi mengelola sampahnya dengan cara dibakar. Setelah adanya kelembagaan partisipatoris di Sungai Cikapundung dengan kegiatan aksi bersih kalinya, terdapat perubahan yang signifikan pada perilaku warga di dua lokasi penelitian, dimana sebesar 100 persen responden di dua kelurahan kini telah menggunakan jasa TPS atau pengangkut sampah dan sudah tidak ada lagi warga yang membuang sampahnya ke Sungai Cikapundung. Efektivitas kelembagaan partisipatoris terlihat dari pernyataan warga Kelurahan Dago yang pada umumnya kini sudah menggunakan jasa pengangkut sampah. Menurut warga RT 02/RW 01 Kelurahan Dago, komunitas CRP telah berhasil mengubah perilaku warga untuk tidak membuang sampah ke Sungai Cikapundung lagi, walaupun terkadang memang masih ada masyarakat yang diam-diam membuang sampah ke Sungai Cikapundung. Sama halnya dengan warga di RT 03/RW 08 Kelurahan Lebak 
Siliwangi yang kini warganya sudah tidak lagi membuang sampah rumah tangga ke Sungai Cikapundung.

Salah satu kegiatan lainnya yang menjadi prioritas bagi kelembagaan partisipatoris Sungai Cikapundung adalah membuat septic tank komunal di beberapa RT dan RW agar pencemaran Sungai Cikapundung dapat diminimalisir dengan mengurangi pipa-pipa santasi yang umumnya dialirkan warga langsung ke Sungai Cikapundung. Jenis sanitasi yang digunakan warga di kedua lokasi penelitian adalah sebagai berikut:

Tabel 8. Jenis Sanitasi yang Digunakan oleh Warga, Sub DAS Cikapundung, Bandung, Jawa Barat, 2011

\begin{tabular}{|c|c|c|c|c|c|c|}
\hline \multirow{3}{*}{ Kelurahan } & \multicolumn{4}{|c|}{ Sanithai } & \multirow{2}{*}{\multicolumn{2}{|c|}{ Total }} \\
\hline & \multicolumn{2}{|c|}{$\begin{array}{l}\text { Mengogumakan } \\
\text { Seppic Cank }\end{array}$} & \multicolumn{2}{|c|}{$\begin{array}{c}\text { Tidak. Vengoumakan Septic } \\
\text { Imolk }\end{array}$} & & \\
\hline & $\begin{array}{l}\text { Jumlh } \\
\text { (Orang })\end{array}$ & Persentase $(\%)$ & $\begin{array}{l}\text { Jumlah } \\
\text { (Orang })\end{array}$ & Persentase $(\%)$ & $\begin{array}{l}\text { Jumlah } \\
\text { (Orange }\end{array}$ & Persentase (\%) \\
\hline Dago & 5 & 17 & 25 & 83,33 & 30 & 100 \\
\hline $\begin{array}{l}\text { Letak } \\
\text { Silitrangl }\end{array}$ & 0 & 0 & 30 & 100 & 30 & 100 \\
\hline
\end{tabular}

Umumnya responden di dua kelurahan baik itu Kelurahan Dago maupun Kelurahan Lebak Siliwangi memiliki karakteristik yang sama, dimana sebesar 83,33 persen responden di Kelurahan Dago dan sebesar 100 persen responden di Kelurahan Lebak Siliwangi sama-sama tidak memiliki septic tank untuk membuang hasil sanitasinya. Responden di kedua lokasi penelitian mengaku bahwa mereka menggunakan Sungai Cikapundung untuk membuang hasil sanitasi lewat pipa-pipa yang langsung dialirkan ke sungai. Responden mengaku mengalirkan hasil sanitasi ke Sungai Cikapundung merupakan suatu hal yang sudah dianggap sangat wajar, karena sudah sejak dahulu dilakukan oleh hampir seluruh warga di daerahnya. Warga tidak terlalu memikirkan dan mempermasalahkan dampak apa yang ditimbulkan terhadap pembuangan hasil sanitasi tersebut. Berikut kesediaan warga untuk mensukseskan pelaksanaan pembuatan septic tank komunal.

Tabel 9. Kesediaan Warga Membuat Septic Tank Setelah Adanya Sosialisasi, Sub DAS Cikapundung, Bandung, Jawa Barat, 2011

\begin{tabular}{|c|c|c|c|c|c|c|}
\hline \multirow{3}{*}{ Keluralan } & \multicolumn{4}{|c|}{ Ilengogumakan Seppic I Imlk } & \multirow{2}{*}{\multicolumn{2}{|c|}{ Iotal }} \\
\hline & \multicolumn{2}{|c|}{ Bersedlin } & \multicolumn{2}{|c|}{ Tildak Bersellia } & & \\
\hline & $\begin{array}{l}\text { Jumlah } \\
\text { (Orange }\end{array}$ & $\begin{array}{c}\text { Persenthrse } \\
(\%)\end{array}$ & $\begin{array}{l}\text { Jumblal } \\
(\text { (lrang })\end{array}$ & $\begin{array}{l}\text { Persentuse } \\
(\%)\end{array}$ & $\begin{array}{l}\text { Jumlal } \\
\text { (Orange }\end{array}$ & $\begin{array}{c}\text { Persenthrese } \\
(\%)\end{array}$ \\
\hline Dago & 12 & 40 & 18 & 60 & 30 & 100 \\
\hline $\begin{array}{l}\text { Levalak } \\
\text { Silirange }\end{array}$ & 9 & 30 & 21 & 70 & 30 & 100 \\
\hline
\end{tabular}

Pada Tabel 9 terlihat bahwa dari 30 orang responden di Kelurahan Dago hanya sebanyak 12 orang atau sebesar 40 persen responden yang bersedia untuk membuat dan menggunakan septic tank komunal, sementara 18 orang lainnya atau sebesar 60 persen responden menyatakan tidak bersedia atas pembuatan septic tank komunal di daerahnya. Untuk kelurahan Lebak Siliwangi hanya sebanyak sembilan orang responden yang bersedia atau sebesar 30 persen yang bersedia atas pembuatan septic tank komunal sementara 21 orang lainnya atau sebesar 70 persen menyatakan tidak bersedia jika tetap dipaksakan untuk membuat septic tank komunal di daerahnya. Dengan adanya program pembuatan septic tank komunal membuat pro-kontra di antara warga di RT 02/RW 01 Kelurahan Dago. Sebagaimana penuturan ketua RT 02/RW 01 yang mengaku warganya tidak setuju dengan adanya pembuatan septic tank komunal. Hal ini dikarenakan septic tank tersebut dibangun di daerah yang terletak dekat dengan rumah beberapa warga.

Untuk pembuatan septic tank komunal, tidak semua RW di Kelurahan Dago dijadikan daerah sasaran, dari 13 RW yang ada di Kelurahan Dago hanya ada beberapa RW saja yang akan dibuat septic tank komunal yaitu di RW 01, 03, 04, 12, dan RW 13. Menurut staf ahli kelurahan yang juga merupakan ketua perkumpulan RW Lebak Siliwangi, permasalahan yang dihadapi dalam merealisasikan septic tank komunal di Kelurahan Lebak Siliwangi adalah ketersediaan lahan. Kelurahan Lebak Siliwangi merupakan pemukiman yang padat, untuk membuat satu septic tank komunal di satu RT saja sudah sangat sulit karena dibutuhkan lahan kosong. Sementara ketersediaan lahan kosong yang tidak ada pemiliknya sudah tidak ada di RT 03/ RW 08. Pembebasan lahan inilah yang menjadi kendala utama untuk pembuatan septic tank komunal, sedangkan untuk sarana dan prasarana pembuatan septic tank komunal sendiri sudah dibantu oleh PDAM dan Bank Dunia. Saat ini, perealisasian septic tank komunal baru dapat dilaksanakan di dua RW saja, dari delapan RW yang ada di Kelurahan Lebak Siliwangi, RW-RW tersebut antara lain RW 05 dan RW 07 saja, itupun tidak pada semua RT di RW tersebut, namun hanya di beberapa RT tertentu saja.

\section{Tingkat Keterlibatan Warga dalam Penghijauan}

Kegiatan lainnya yang telah dilakukan oleh kelembagaan partisipatoris Sungai Cikapundung adalah penghijauan atau penanaman pohon. Untuk kegiatan penghijauan di Kelurahan Lebak Siliwangi, hal ini tidak terlalu sering dilakukan dikarenakan lahan kosong atau lahan kritis di RT 03/ RW 08 Kelurahan Lebak Siliwangi, Kecamatan Coblong Bandung Barat, sudah sangat sedikit, serta rumah antar warga sangat berdekatan sehingga untuk menanam pohon atau sekedar menanam tanaman sudah sangat sulit, menurut responden di Kelurahan Lebak Siliwangi penghijauan atau penanaman pohon hanya beberapa kali saja dilakukan dalam satu tahun di daerahnya.

Berbeda halnya dengan Kelurahan Dago dimana kegiatan penghijauan atau penanaman pohon memang sudah ada sejak dahulu kala, namun setelah adanya komunitas CRP, kegiatan penghijauan semakin gencar dilaksanakan. Berikut pasrtisipasi masyarakat dalam kegiatan penghijauan yang diadakan oleh kelembagaan partisipatoris Sungai Cikapundung di dua lokasi 
penelitian. Dari data diatas dapat disimpulkan bahwa partisipasi warga dalam setiap kegiatan penghijauan yang diadakan oleh kelembagaan partisipatoris masih sangat rendah. Namun hal ini dapat dijelaskan dengan alasan sebagai berikut.

Rata-rata responden yang mengikuti kegiatan penghijauan dikarenakan kesadaran akan ruang terbuka hijau saat ini yang sudah sangat memprihatinkan. Responden di kedua lokasi penelitian mengaku bahwa dalam setiap kegiatan penghijauan baik yang diadakan oleh komunitas CRP dan komunitas Zero senantiasa selalu mengajak warga untuk turut berperan serta dan melakukan aksi penghijauan langsung di tempat. Untuk Kelurahan Dago, rata-rata penghijauan yang dilakukan lima hingga sepuluh kali dalam satu tahun. Sementara untuk di Kelurahan Lebak Siliwangi frekuensi kegiatan penghijauan lebih rendah dibandingkan dengan di Kelurahan Dago dimana responden menjawab penghijauan yang dilakukan di daerahnya hanya sebanyak tiga hingga tujuh kali dalam satu tahun. Selanjutnya pada Gambar 8. memperlihatkan apakah kegiatan penghijauan yang diadakan oleh kelembagaan partisipatoris dapat memicu kegiatan yang serupa di dua lokasi penelitian.

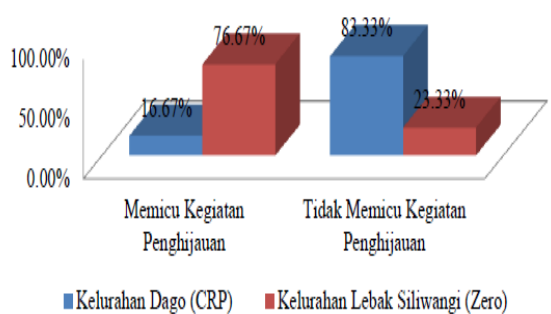

Gambar 8. Penganuh Kegiatan Kelembagaan Partisipatoris Terhadap Kegiatan Penghijauan di Daerah Warga, Sub DAS Cikapundung, Jawa Barat, 2011

Pada Gambar 8. diperlihatkan bahwa kegiatan penghijauan yang dilakukan oleh kelembagaan partisipatoris kurang memicu kegiatan serupa di Kelurahan Dago dimana responden yang menyatakan kegiatan penghijauan yang diadakan oleh komunitas CRP memicu kegiatan serupa di daerahnya hanya sebesar 16,67 persen. Berbeda halnya dengan Kelurahan Lebak Siliwangi dimana responden menjawab 76,67 persen kegiatan-kegiatan komunitas Zero memicu dan menginisiasi warga untuk melakukan kegiatan serupa di daerahnya. Berikut pernyataan responden dari kedua kelurahan yang berbeda.

Menurut salah seorang anggota komunitas CRP yang juga merupakan warga RT 02/RW 01, walaupun dengan adanya keberadaan komunitas CRP di lingkungannya berpengaruh terhadap kelestarian Sungai Cikapundung dan ruang terbuka hijau, namun partisipasi warga RT 02/RW 01 di hampir setiap kegiatan lingkungan yang diadakan oleh komunitas CRP sangat rendah. Selain solidaritas yang tidak begitu kuat, warga RT 02/RW 01 memang memiliki permasalahan dengan komunitas CRP terkait persoalan septic tank komunal. Kegiatan-kegitan komunitas CRP lebih banyak diminati dan digemari oleh anak remaja dibandingkan oleh orang dewasa di RT 02/ RW 01. Umumnya remaja - remaja tersebut merupakan remaja yang telah putus sekolah serta tidak memiliki pekerjaan apapun. Remaja-remaja tersebut sangat membantu anggota komunitas CRP dalam mengambil sampah-sampah dari sungai dan sebagai tenaga tambahan dalam setiap kegiatan yang diadakan oleh komunitas. Berbeda dengan pernyataan salah seorang warga RT 03/RW 08 Kelurahan Lebak Siliwangi dimana sudah mulai terlihat perubahan sikap dan perilaku warganya dalam kegiatan penghijauan.Penanaman tumbuhan hijau dengan menggunakan pot tersebut merupakan instruksi langsung yang diberikan ketua RW 08 yang juga merupakan ketua komunitas Zero kepada seluruh warganya khususnya warga RT 03/RW 08. Selanjutnya berikut disajikan data mengenai partisipasi warga dalam setiap kegiatan penghijauan atau penanaman pohon di daerahnya yang dikategorikan menjadi empat kategori yaitu selalu melakukan kegiatan penghijauan di daerahnya, kadang-kadang saja mengikuti penghijauan, jarang mengikuti kegiatan penghijauan, dan terakhir tidak pernah mengikuti kegiatan penghijauan di daerahnya.

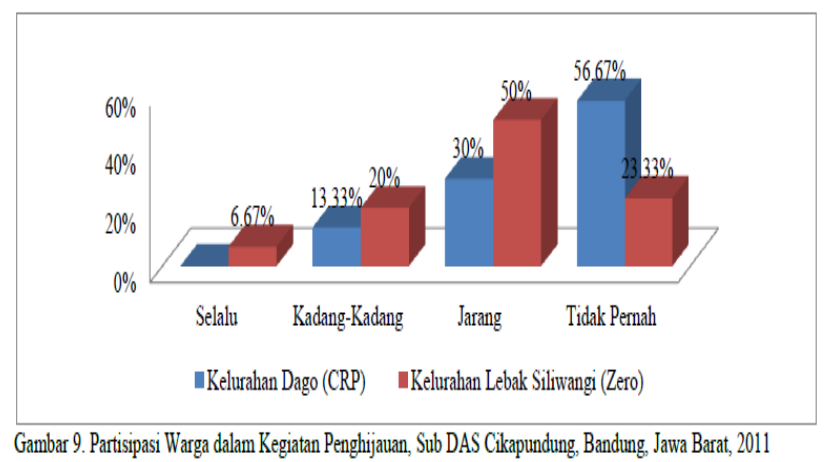

Gambar 9. memperlihatkan bahwa partisipasi warga di kedua kelurahan dalam setiap kegiatan penghijauan dapat dikatakan tergolong rendah dimana sebanyak 56,67 persen warga Kelurahan Dago menjawab tidak pernah ikut kegiatan penghijauan atau penanaman pohon di daerahnya, sementara 30 persen lainnya menjawab jarang dan 13,33 persen lainnya menjawab kadang-kadang saja mengikuti kegiatan penghijauan. Untuk Kelurahan Lebak Siliwangi responden yang menjawab tidak pernah mengikuti kegiatan penghijauan di daerahnya yaitu sebanyak 23,33 persen, menjawab jarang sebesar 50 persen, kadang-kadang sebesar 20 persen dan yang menjawab selalu sebesar 6,67 persen. Dapat disimpulkan bahwa partisipasi warga yang berlokasi sudah ke tengah Sungai Cikapundung lebih baik dalam kegiatan penghijauan dibandingkan dengan warga di Kelurahan Dago yang berada di daerah hulu dan masih memiliki banyak lahan kosong. Hal ini dikaitkan kembali dengan rasa solidaritas dan gotong royong diantara warga di setiap kelurahan. Umumnya warga di Kelurahan Lebak Siliwangi yang sudah memasuki kawasan tengah Sungai Cikapundung memiliki rasa solidaritas dan gotong royong yang lebih kuat dibandingkan dengan warga di Kelurahan Dago yang merupakan kawasan hulu Sungai Cikapundung, diakarenakan para elit politik seperti RT, RW, komunitas, karang taruna dan lain sebagainya saling bekerjasama dalam setiap permasalahan lingkungan yang muncul di daerahnya. Rata - rata warga RT 03/RW 08 Kelurahan Lebak Siliwangi yang menanam tumbuhan hijau di pekarangan rumahnya adalah warga yang rumahnya menghadap langsung ke jalan raya dan tidak 
berada di dalam gang-gang kecil, dimana responden yang tinggal di dalam gang kecil mengaku tidak memiliki lahan yang cukup bahkan hanya untuk menyimpan pot. Warga RT 02/RW 01 Kelurahan Dago secara kasat mata melihat memang jarang sekali ada yang menanam tumbuh-tumbuhan atau tanaman hias di pekarangannya.

\section{Tingkat Keterlibatan Warga dalam Kegiatan Gotong Royong}

Berbeda halnya dengan asas gotong royong di Kelurahan Lebak Siliwangi yang sebelumnya telah lama ada, setelah adanya komunitas Zero, kegiatan semacam gotong semakin gencar dilaksanakan atas inisiatif warga sendiri. Sebelumnya, di Kelurahan Lebak Siliwangi tidak ada semacam komunitas-komunitas pegiat lingkungan, namun setelah masuknya komunitas CRP ke daerah Lebak Siliwangi, kini sudah ada beberapa komunitas pegiat sungai di Kelurahan Lebak Siliwangi. Dari delapan RW di Kelurahan Lebak Sliwangi kini telah ada lima komunitas pegiat Sungai Cikapundung dengan berbagai nama yang berbeda yang ditempatkan di beberapa RW. Berikut frekuensi kegiatan gotong royong di dua lokasi penelitian sebelum dan setelah adanya kelembagaan partisipatoris Sungai Cikapundung sebagaimana Gambar 10 di bawah ini:

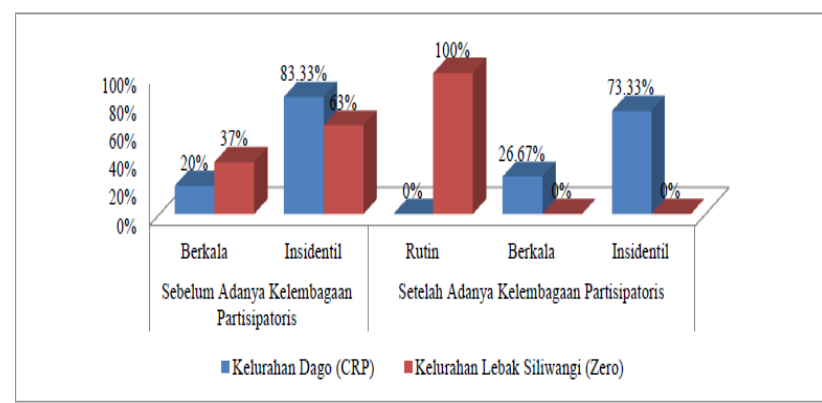

Gambar 10 Kegiatan Gotong Royong di Daerah Warga Sebelum dan Setelah Adanya Kelembagaan Partisipatoris, Sub DAS Cikapundung, Bandung, Jawa Barat, 2011

Kegiatan gotong royong sebelum adanya kelembagaan partisipatoris Sungai Cikapundung di Kelurahan Dago umumnya dilakukan secara insidentil dimana responden menjawab sebesar 83,33 persen, sisanya sebesar 20 persen responden menjawab bahwa gotong royong di daerahnya dilakukan secara berkala. Untuk Kelurahan Lebak Siliwangi responden yang menjawab gotong royong di daerahnya dilakukan secara insidentil sebesar 63,33 persen dan yang menjawab berkala ada sebanyak 37 persen. Setelah adanya kegiatan kelembagaan partisipatoris di Sungai Cikapundung terjadi perubahan frekuensi kegiatan gotong royong dimana 100 persen responden di RT 03/ RW 08 Kelurahan Lebak Siliwangi menjawab bahwa kegiatan gotong royong di daerahnya dilakukan secara rutin yaitu seminggu sekali tepatnya dilaksanakan pada hari sabtu pagi. Berbeda dengan Kelurahan Dago yang hampir tidak ada perubahan dari sebelum adanya kegiatan kelembagaan partisipatoris, dimana sebanyak 73,33 persen responden menyatakan kegiatan gotong royong di daerahnya bersifat insidentil dan sebesar 26,67 persen menjawab gotong royong dilakukan secara berkala hanya menjelang hari-hari besar saja. Berikut pernyataan salah seorang anggota komunitas Zero di Kelurahan Lebak Siliwangi yang juga warga asli RT 03/RW 08.
Partisipasi responden dalam setiap kegiatan gotong royong dikategorikan menjadi empat kategori yaitu selalu, kadang-kadang, jarang dan tidak pernah, berikut persentase warga yang mengikuti kegiatan gotong royong di daerahnya dipaparkan dalam Gambar 11.

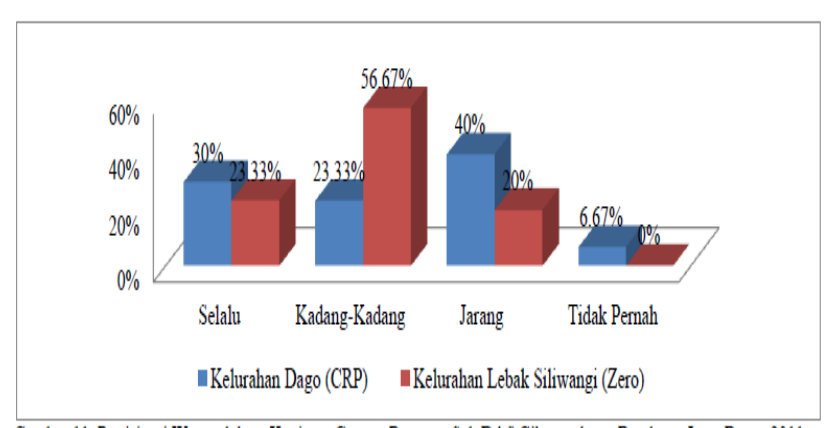

Gambar 11. Partisipasi Warga dalam Kegiatan Gotong Royong, Sub DAS Cikapundung, Bandung, Jawa Barat, 2011

Pada Gambar 11 partisipasi responden dalam kegiatan gotong royong di dua lokasi penelitian tidaklah jauh berbeda dimana sebesar 30 persen responden di Kelurahan Dago menjawab selalu mengikuti kegiatan gotong royong di daerahnya, sementara 23,33 persen lainnya menjawab kadang-kadang saja mengikuti kegiatan gotong royong, 40 persen lainnya menjawab jarang mengikuti kegiatan gotong royong dan 6,67 persen responden menyatakan tidak pernah mengikuti kegiatan gotong royong di daerahnya. Untuk tingkat partisipasi di Kelurahan Lebak Siliwangi, responden yang menjawab selalu dalam setiap kegiatan gotong royong sebesar 23,33 persen, kadang-kadang sebesar 56,67 persen dan menjawab jarang sebesar 20 persen. Ketidakhadiran responden di dua lokasi penelitian memiliki berbagai macam alasan, namun pada umumnya dua alasan responden tidak mengikuti kegiatan gotong royong adalah karena disibukkan dengan pekerjaannya serta berbagai acara keluarga sehingga berbentrokan dengan waktu dilaksanakannya gotong royong dan juga karena masalah informasi dimana banyak warga yang tidak tahu bahwa akan diadakan kegiatan gotong royong di daerahnya. Komunitas CRP dan komunitas Zero yang berada di dua lokasi penelitian selalu melakukan aksi bersih-bersih Sungai Cikapundung, hal ini diterapkan komunitas sebagai salah satu bentuk kegiatan gotong royong bersama-sama dengan warga. Berikut partisipasi warga dalam kegiatan bersih-bersih sungai yang biasanya dilakukan secara rutin setiap hari oleh komunitas.

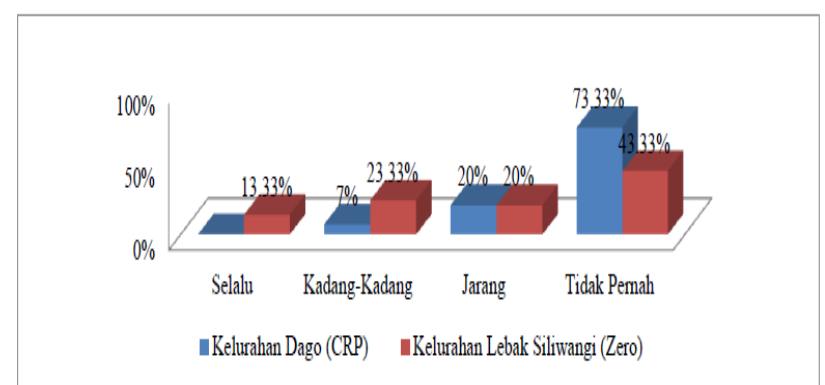

Gambar 12. Partisipasi Warga dalam Kegiatan Bersih-Bersih Sungai, Sub DAS Cikapundung, Bandung, Jawa Barat, 2011

Gambar 8 memperlihatkan bahwa sebesar tujuh persen responden di Kelurahan Dago menjawab kadang-kadang saja mengikuti kegiatan bersih-bersih, responden yang menjawab jarang sebesar 20 persen dan yang tidak pernah 
sama sekali mengikuti kegiatan bersih-bersih sungai yaitu 73,33 persen. Responden di Kelurahan Lebak Siliwangi yang selalu mengikuti kegiatan bersih-bersih sungai, sebesar 13,33 persen, 23,33 persen menjawab kadangkadang saja mengikuti kegiatan bersih-bersih sungai, 20 persen lainnya menjawab jarang dan sebesar 43,33 persen mengaku tidak pernah mengikuti kegiatan bersih-bersih sungai di daerahnya. Persentase yang rendah di dua kelurahan ini terjadi karena kegiatan bersih-bersih sungai merupakan kegiatan yang wajib dilaksanakan hanya bagi anggota komunitas CRP dan komunitas Zero saja. Bagi warga biasa kegiatan bersih-bersih sungai bukan merupakan hal yang wajib diikuti dalam setiap kegiatan gotong royong serta pada umumnya kegiatan bersihbersih atau susur sungai kebanyakan dilakukan oleh bapak-bapak dan para pemuda. Hal ini sebagaimana pernyataan humas komunitas Zero. Setiap kegiatan gotong royong baik itu di Kelurahan Dago maupun Kelurahan Lebak Siliwangi, membutuhkan peralatan untuk digunakan warga dalam kegiatan gotong-royong ataupun bersih-bersih sungai, peralatan tersebut merupakan hasil swadaya warga. Penelitian ini juga mengukur tingkat partisipasi responden dalam kegiatan rapat-rapat, perbaikan dan pemeliharaan lingkungan di dua kelurahan setelah adanya kelembagaan partisipatoris, sebagaimana disajikan pada Gambar 13.

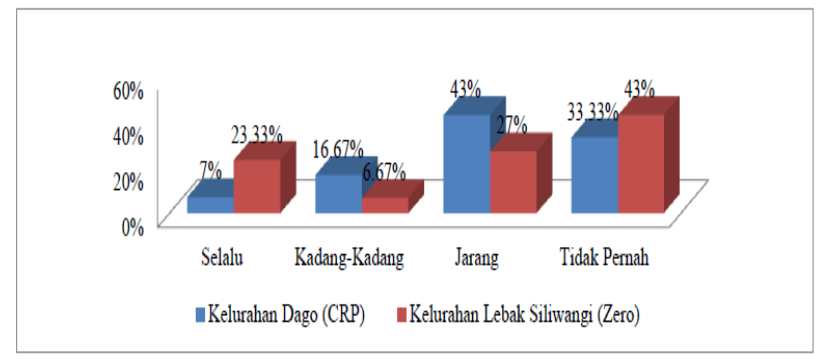

Gambar 13. Partisipasi Warga dalam Rapat-Rapat Perbaikan dan Pemeliharaan Lingkungan Setelah Adanya Kelembagaan Partisipatoris Sub DAS Cikapundung, Bandung, Jawa Barat, 2011

Pada Gambar 13. terlihat responden di Kelurahan Dago yang selalu mengikuti kegiatan rapat-rapat perbaikan dan pemeliharaan lingkungan sebesar tujuh persen, yang menjawab kadang-kadang sebesar 16,67 persen, menjawab jarang sebesar 43 persen dan yang tidak pernah ikut kegiatan rapat-rapat perbaikan dan pemeliharaan lingkungan sebesar 33,33 persen. Responden Kelurahan Lebak Siliwangi yang mengikuti kegiatan rapat-rapat perbaikan dan pemeliharaan lingkungan jumlahnya lebih tinggi dibandingkan dengan Kelurahan Dago yaitu sebesar 23,33 persen sementara yang menjawab kadangkadang hanya sebesar 6,67 persen dan yang menjawab jarang sebesar 27 persen, terakhir responden yang tidak pernah mengikuti kegiatan rapat-rapat perbaikan dan pemeliharaan sungai ada sebesar 43 persen lebih tinggi daripada jumlah responden di Kelurahan Dago. Kegiatan rapat ini dilakukan bila terjadi permasalahan lingkungan di kedua daerah, terjadinya perbedaan partisipasi diantara kedua kelurahan disebabkan oleh para pemangku kepentingan serta lembaga yang berlaku di masyarakat. Bila dilihat ketua RT 03 dan RW 08 serta lembaga masyarakat yang berada di Kelurahan Lebak Siliwangi cenderung lebih solid dibandingkan dengan yang ada di RT 02/ RW 01 Kelurahan Dago. Warga RT 03/ RW 08 mengaku setelah adanya kegiatan bersih-bersih setiap hari sabtu dan minggu maka semangat untuk bergotong royong lebih terasa, tidak seperti dahulu dimana kegiatan gotong-royong waktunya tidak menentu dan bersifat berkala ataupun insidental. Setelah adanya komunitas Zero banyak diadakan kegiatan-kegiatan yang memperkuat solidaritas antar warga, salah satunya pertandingan olahraga antar RT.

Adanya perbedaan partisipasi warga dalam kegiatan lingkungan di dua kelurahan yaitu Kelurahan Dago dan Kelurahan Lebak Siliwangi disebabkan karena perbedaan visi misi diantara komunitas pegiat Sungai Cikapundung di daerahnya masing-masing. Kegiatan-kegiatan komunitas CRP di Kelurahan Dago lebih memfokuskan pada kegiatan penyadaran warga di sepanjang bantaran Sungai Cikapundung dimana fokus utamanya mengatur, mengkoordinir dan menjalin kerjasama dengan berbagai pemangku kepentingan (42 komunitas pegiat Sungai Cikapundung, swasta, akademisi, pemerintah dan lain sebagainya) terkait kelestarian Sungai Cikapundung. Umumnya komunitas CRP memiliki berbagai agenda kegiatan lingkungan di luar Kelurahan Dago itu sendiri khususnya terkait Sungai Cikapundung yang cakupannya luas (tidak fokus hanya pada satu daerah/RW/RT saja). Berbeda halnya dengan komunitas Zero di Kelurahan Lebak Siliwangi yang memang dibentuk bersama-sama oleh warga RW 08 dan untuk warga RW 08 itu sendiri, dimana cakupan kerjanya lebih sempit dibandingkan dengan komunitas CRP serta solidaritas diantara warganya lebih erat karena memiliki rasa yang sama dalam menghadapi permasalahan lingkungan khususnya terkait kelestarian Sungai Cikapundung. Umumnya warga di Kelurahan Dago memiliki rasa solidaritas dan gotong- royong yang lebih rendah dibandingkan dengan warga di Kelurahan Lebak Siliwangi. Hal ini terjadi karena kebersamaan/solidaritas/gotong-royong hanya akan muncul ketika warga memiliki satu permasalahan serupa sehingga memiliki visi yang sama untuk menyelesaikannya, begitupun dengan apa yang terjadi pada Kelurahan Lebak Siliwangi dimana permasalahan yang muncul adalah banyaknya sampah di bantaran Sungai Cikapundung. Perubahan perilaku yang terjadi saat ini khususnya pada warga RT 03/ RW 08 Kelurahan Lebak Siliwangi merupakan hasil kerjasama yang baik dari seluruh pihak.

\section{KESIMPULAN}

Hasil penelitian menunjukkan terbentuknya kelembagaan partisipatoris di hulu DAS Citarum (Sub DAS Cikapundung) berawal dari terjalinnya kerjasama diantara masyarakat di bantaran Sungai Cikapundung yang memiliki visi misi menyelamatkan sungai dari kerusakan. Upaya penyelamatan Sungai Cikapundung di Kota Bandung pun didukung oleh kerjasama dari berbagai pemangku kepentingan yang ada mulai dari masyarakat, pemerintah Kota Bandung, swasta maupun akademisi. Kerjasama diantara pemangku kepentingan di Kota Bandung ini pun menampakkan hasil, dimana secara kasat mata dari tahun ke tahun kualitas air Sungai Cikapundung semakin baik (berkurangnya sampah).

Efektivitas kelembagaan partisipatoris yang selama ini melakukan berbagai kegiatan penyelamatan Sub DAS 
Cikapundung terlihat dari telah berhasilnya kelembagaan partisipatoris dalam menyadarkan dan mengubah perilaku warga di beberapa bantaran sungai untuk tidak membuang sampah ke sungai lagi. Namun, untuk penyadaran dalam hal pengelolaan sampah dan penghijauan masih kurang berpengaruh terhadap perilaku warga, dimana partisipasi warga masih sangat rendah. Kelembagaan partisipatoris pun belum berhasil menyadarkan warga di dua kelurahan untuk membuat septic tank komunal karena terbentur banyaknya kendala seperti pembebasan lahan kosong serta masih banyaknya pro dan kontra diantara warga yang tidak setuju dengan adanya program septic tank komunal sekalipun sudah ada campur tangan Walikota, Lurah, RW, dan RT. Kelembagaan partisipatoris memiliki pengaruh yang berbeda terhadap warga di dua kelurahan dimana warga Kelurahan Dago yang pada umumnya berada di wilayah hulu Sungai Cikapundung pada kenyataannya memiliki partisipasi yang jauh lebih rendah di bidang lingkungan dibandingkan warga di tengah Sungai Cikapundung yaitu Kelurahan Lebak Siliwangi.

Adanya batas wilayah kerja Kota dengan Kabupaten Bandung membuat upaya penyelamatan di hulu Sungai Cikapundung tidak menyeluruh, dimana semangat untuk merevitalisasi sungai hanya ada di Kota Bandung saja, hal ini dikarenakan di wilayah Kabupaten Bandung belum terdapat komunitas-komunitas pegiat sungai seperti yang telah ada di Kota Bandung. Kelembagaan partisipatoris tidak berdaya menyadarkan serta mengubah perilaku para pengusaha yang memanfaatkan sungai untuk tidak lagi membuang hasil limbah mereka ke Sungai Cikapundung khususnya pengusaha di daerah Kabupaten Bandung Barat.

\section{SARAN}

Beberapa saran yang dapat diajukan dari hasil penelitian ini, anatara lain:

1. Diperlukan koordinasi dan kolaborasi dari berbagai pemangku kepentingan baik itu, pemerintah, masyarakat, swasta, serta pihak akademisi mulai dari hulu, tengah maupun hilir untuk bersama-sama menjaga dan melestarikan Sungai Cikapundung.

2. Diperlukan ketegasan dari pemerintah daerah khususnya Kabupaten Bandung dengan mengeluarkan kebijakan dan sanksi untuk mengatasi para pihak yang memanfaatkan hulu Das Citarum, (Sub DAS Cikapundung) secara tidak bertanggung jawab khususnya pihak swasta dan pengusaha.

3. Diperlukan komunitas lingkungan di Kabupaten Bandung Barat yang khusus menangani permasalahan lingkungan (industri peternakan sapi).

4. Diperlukan kesadaran dari berbagai pihak bahwa Sungai Cikapundung dapat dijadikan tempat wisata yang dapat membangun kembali citra Sungai Cikapundung agar menjadi sungai kebanggaan di Kota Bandung.

5. Pemerintah setempat harus mengaplikasikan pembanguanan kota yang berwawasan kelestarian lingkungan sebagaimana yang tercantum dalam pasal 1 ayat 3 UU No. 32 Tahun 2009: tentang Perlindungan dan Pengelolaan Lingkungan Hidup adalah upaya sadar dan terencana yang memadukan aspek lingkungan hidup, sosial dan ekonomi ke dalam strategi pembangunan untuk menjamin keutuhan lingkungan hidup serta keselamatan, kemampuan, kesejahteraan, dan mutu hidup generasi masa kini dan generasi masa depan.

6. Sungai Cikapundung harus dipandang sebagai satu kesatuan ekosistem mulai dari hulu, tengah dan hilir serta pengelolaan yang mengacu pada pembangunan yang berkelanjutan dimana sungai tidak hanya dilihat dari sisi ekonomis saja namun juga dari sisi sosial dan ekologi sehingga dapat diwariskan kepada generasi selanjutnya.

7. Melihat lingkungan yang cukup asri dan potensi wisata maka untuk mengembangkan Sungai Cikapundung menjadi objek wisata diperlukan kerjasama dari dinas-dinas terkait terutrama dinas budaya pariwisata, pihak swasta maupun masyarakat yang nantinya menjadi pengelola utama Sungai Cikapundung.

8. Upaya penyelamatan DAS Citarum (Sub DAS Cikapundung) tidak serta merta harus langsung pada arena kolaboratif sub DAS hulu-tengah-hilir, namun upaya kolaboratif sebaiknya terlebih dahulu dilakukan di masing- masing sub DAS (kolaborasi dalam sub DAS), hal ini dilakukan agar kolaboratif dilakukan secara holistik di setiap lini sub DAS tanpa terkecuali. Jikalau kolaborasi di masing-masing sub DAS sudah kuat, kini tinggal bagaimana menyatukan kepentingan antar sub DAS yang ada yaitu antara sub DAS hulu, tengah hingga hilir (kolaborasi antar sub DAS).

\section{DAFTAR PUSTAKA}

Agusta, I. 1998. Cara Mudah Menggunakan Metode Kualitatif pada Sosiologi Pedesaan. Kelompok Dokumentasi Ilmu Sosial IPB. Bogor.

Arifin, B. 2001. Pengelolaan Sumberdaya Alam Indonesia (Perspektif Ekonomi, Etika, dan Praksis Kebijakan). Jakarta: Erlangga.

Arimbi. 1993. Peran Serta Masyarakat dalam Pengelolaan Lingkungan. Jakarta: Walhi.

Atmanto. 1995. Peran Pemerintah dan Partisipasi Masyarakat dalam Pembangunan Hutan Kota: Studi Kasus di Kelurahan Krobokan Kecamatan Semarang Barat, Kotamadya Semarang. Bogor: Tesis. Program Pascasarjana Institut Pertanian Bogor.

Barber, C.V, et al. 1997. Meluruskan Arah Pelestarian Keanekaragaman Hayati dan Pembangunan di Indonesia. Jakarta: Yayasan Obor Indonesia.

[Dephut] dan IPB. 2003a. Rencana Pengelolaan DAS Terpadu DAS Ciliwung. Bogor: Kerjasama antara Balai Pengelolaan DAS Citarum-Ciliwung Departemen Kehutanan dengan Fakultas Kehutanan Institut Pertanian Bogor. 
[Dephut]. 2003b. Pedoman Pembentukan Forum DAS. Jakarta: Direktorat Pengelolaa DAS dan Rehabilitasi Lahan. [Dephut]. 2003c. Kajian Model Pengelolaan Daerah Aliran Sungai (DAS) Terpadu. Jakarta: Kehutanan dan Konservasi Sumberdaya Air.

[Dephut]. 2006. Peraturan Menteri Kehutanan No. P.26/Menhut-II/2006 tentang Pedoman Penyusunan Rencana Pengelolaan DAS Terpadu. Jakarta: Departemen Kehutanan.

[Dephut]. 2008. Kerangka Kerja Pengelolaan Daerah Aliran Sungai di Indonesia. Jakarta: Departmen Kehutanan Republik Indonesia.

[Dephut]. 2009. Peraturan Menteri Kehutanan No. P.42/Menhut-II/2009 tentang Pola Umum, Kriteria dan Standar Pengelolaan Daerah Aliran Sungai Terpadu. Jakarta : Direktorat Jenderal Rehabilitasi Lahan dan Perhutanan Sosial.

Dharmawan, A. H. et al. 2005. Pembaharuan Tata Pemerintahan Lingkungan (Menciptakan Ruang Kemitraan Negara- Masyarakat Sipil-Swasta). Bogor: Kerjasama Pusat Studi Pembanguanan (PSP) Institut Pertanian Bogor dengan Partnership For Governance Reform in Indonesia UNDP.

Djogo, T et al. 2003. Kelembagaan dan Kebijakan dalam Pengembangan Agroforestry. Bogor: World Agroforesry Centre (ICRAF).

Farida et al. 2005. Penilaian Cepat Hidrologis: Pendekatan Terpadu dalam Menilai Fungsi Daerah Aliran Sungai (DAS). Bogor: Rewarding Upland Poor for Environmental Services (RUPES) Program World Agroforestry Centre (ICRAF).

Hadi, $\mathrm{H}$ et al. 2006. Pengelolaan Daerah Aliran Sungai: Sebuah Pendekatan Negosisasi. Yogyakarta: INSISTpress. Intania, O. I. 2003. Tingkat Partisipasi Masyarakat dalam Program Penanggulangan Kemiskinan di Perkotaan (P2KP). Bogor: Skripsi. Jurusan Sosial Ekonomi. Fakultas Pertanian IPB.

Kartodihardjo, H et al. 2004. Institusi Pengelolaan Daerah Aliran Sungai (Konsep dan Pengantar Analisis Kebijakan. Bogor; Fakultas Kehutanan Institut Pertanian Bogor.

Karyana, A. 2007. Analisis Posisi dan Peran Lembaga Serta Pengembangan Kelembagaan di Daerah Aliran Sungai (DAS) Ciliwung. Bogor: Sekolah Pascasarjana Institut Pertanian Bogor.

Manik, K. E. S et al. 2010. Kelembagaan Dalam Pengelolaan Daerah Sungai (DAS). Pekanbaru: Ilmu Tanah Fakultas Pertanian Unila dan Jurusan Kehutanan Fakultas Pertanian Unila (Konferensi dan Seminar BKPSL Indonesia). Means, $\mathrm{K}$ et al. 2005. Kolaborasi dan Konflik. Sinergi: Jurnal Manajemen Kolaborasi Vol. I, No. 1, Hal 21-30.

Nasdian, F. T. 2004. Perspektif Kelembagaan dalam Pengelolaan DAS Citanduy (Study Desentralisasi
Pengelolaan dan Sistem Tata Pemerintahan Alam). Bogor: Project Working Paper. Institut Pertanian Bogor.

Nugroho dan Dahuri. 2004. Pembangunan Wilayah (Perspektif Ekonomi, Sosial dan Lingkungan). Jakarta: LP3ES. Pasya, G et al. 2002. Sistem Pendukung Negosiasi Multi Tataran Dalam Pengelolaan Sumberdaya Alam Secara Terpadu: Dari Konsep Hingga Praktek. Bogor: World Agroforestry Centre, Hal 8-19. Purba, J. 2002. Pengelolaan Lingkungan Sosial. Jakarta: Yayasan Obor Indonesia.

Puslitbang. 2007. Pengembangan dan Pembaharuan Data Kualitas Lingkungan Keairan. Bandung: Pusat Penelitian dan Pengembangan Sumberdaya Alam.

Raharja, S. J. 2010. Pendekatan Kolaboratif Pengelolaan Daerah Aliran Sungai. Bandung: Program Pasca Sarjana Fakultas Ilmu Sosial dan Ilmu Politik Universitas Padjajaran.

Setiadi, D et al. 2010. Penuntun Praktikum Ilmu Lingkungan. Bogor: Laboratorium Ekologi Departemen Biologi, Fakultas Matematika dan Ilmu Pengetahuan Alam Institut Pertanian Bogor.

Singarimbun, Masri dan Sofian Effendi. 1989. Metode Penelitian Survai. Jakarta: LP3ES.

Suganda, E et al. 2009. Pengelolaan Lingkungan dan Kondisi Masyarakat Pada Wilayah Hilir Sungai. Makara, Sosial Humaniora, Vol. 13, No 2, Hal 143-153.

Sugandhy, A. 2007. Prinsip Dasar Kebijakan Pembangunan Berkelanjutan Berwawasan Lingkungan. Jakarta: PT Bumi Aksara.

Sugiyono. 2008. Metode Penelitian Kuantitatif, Kualitatif dan R \& D. Bandung: Alfabeta.

Sumampouw, M et al. Tanpa Tahun. Satu Kelola Satu Rasa Satu Aksi Sejuta Manfaat (Sebuah Panduan Pengelolaan DAS Skala Kecil). Kerjasama BAPPENAS, USAID, ESP, Departemen Kehutanan. Suporahardjo. 2005. Manajemen Kolaborasi. Bogor: LATIN

Zulkarnain dan Dodo. 1989. Pembangunan Berorientasi Kerakyatan, Sebuah Model Radiasi LSM. Yogyakarta: Makalah dalam Pembangunan Masyarakat Pedesaan UGM. 